\title{
LIQUEFIED NATURAL GAS DEVELOPMENT: OVERVIEW AND THE GROWTH OF FUTURE GAS SUPPLY FOR THE NORTH AMERICAN MARKET
}

\author{
Michael J. Black, Peter A. Bryan”“ and Jeffrey D. Scobie”“
}

The business of liquefied natural gas (l.NG) has ven quickly become a topical and important energy concern. While the liquefication process has been developed and refined for a number of decades and importation of LNG is an accepted practice in the Middle East, Japan, Korea and paris of Europe, it is a relatively new source of supply in North America. However, increased North American demand for natural gas, coupled with diminishing production from accessible basins in Western Canada and the reduced costs and efficiencies of ships, liquefaction plants and storage terminals. have rendered LNG a viable and price competitive supply alternative.

The LNG indusiry provides unique challenges 10 producers, regulators, consumers and stakeholders. Producers must not only negotiate development, joint venture and sale and purchase agreements, but also arrange for shipping and transportation and terminal services agreements. In North America. while regulators have divided jurisdiction over $L N G$ terminal facilities on the basis of the location of the facility, the stage of production and the degree of integration with related infrasintucture, they also appear to be encouraging firther development by facilitating regulatory approval.

As the Fainwinds and Qatar Petroleum projects demonstrate. the evolution of the LNG indusiny is dependent upon a delicate collaboration of governments, regulators, producers, financiers, consumers and stakeholders.
Le secteur dus gaz naturel liquéfie (GNL) est rapidement devenu une préoccupation énergésigute importante ef d'actualité. Bien que le processus de liquéfaction er de raffinage ait été mis au point ll y a des dizaines d'annees el que l'importation de GNL soit une pratique accepté au Proche-Orient, au Japon, en Corée et dans des régions en Europe, il représenle une source d'approvisionnement nowvelle en Amérique du Nord. Cependant, la demande nord. américaine de gaz naturel, alliee à une production réduite des bassins accessibles dans l'ouest du Canada er les coưts réduits et conomies réalisées par le transport en batean. les usines de liquéfaction et les terminaux d'entreposage ont fait dit GNL une alternative d'approvisionnement viable à un couit concurrentiel.

Le secleur du GNL fournit des occasions uniques pour les producteurs, les organismes de réglementation, les consommateurs et les intervenants. Les producteurs ne doivent pas seulement négocier la mise en valeur. les projets conjoints, la vente et l'achat d ententes, ils doivent aussi soccuper de l'expedition et du transport ainsi que des ententes de services de terminaux. En Amerigue du Nord, alors que les organismes de réglementation ont des compétences partagées en matière d'installations de terminaux de GNL selon I emplacement des insiallations. I'isape de production et le degré d'intégration dans l'infrastructure connexe. its semblent aussi encourager d'autres développements en factiliant l'approbation réglementaire.

Comme le prouvenl les projets pétroliers Fainwinds et du Qatar. I'évolution du secteur du GNL est Iributaire de la dificate collaboration des gouvernements, des organismes de riglententation. des producteurs, des financiers, des consommateurs ef des intervenamis.

\section{TABLE OF CONTENTS}

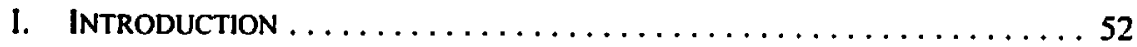

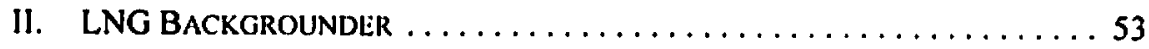

- Partner, Heenan Blaikie LLP, Calgary, Alberta. The author wishes to thank Anita Dusevic and Jillian

Frank of Heenan Blaikie LLP for their assistance in connection with this article.

-. Lcgal Counsel, TransCanada PipeLines Limited, Calgary. Alberta.

-.. General Counsel, Qatar Petroleum, Doha, Qutar. 
A. WHAT IS LNG? $\ldots \ldots \ldots \ldots \ldots \ldots \ldots \ldots \ldots \ldots \ldots \ldots$

B. A BRIEF HISTORY OF THE GLOBAL LNG INDUSTRY ......... 54

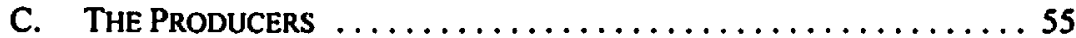

III. NORTH AMERICAN CONTEXT $\ldots \ldots \ldots \ldots \ldots \ldots \ldots \ldots \ldots \ldots \ldots \ldots$

A. CURRENT SUPPLY AND DEMAND

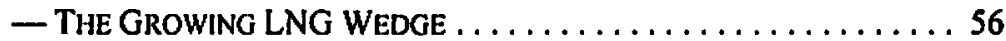

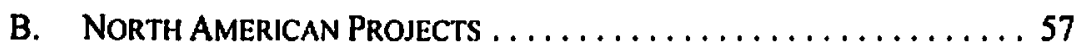

C. Commercial Issues $\ldots \ldots \ldots \ldots \ldots \ldots \ldots \ldots \ldots \ldots \ldots \ldots$

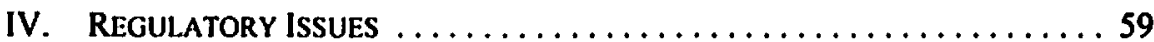

A. Canadian Regulation of LNG $\ldots \ldots \ldots \ldots \ldots \ldots \ldots, 60$

B. AMERICAN REGULATION OF LNG $\ldots \ldots \ldots \ldots \ldots \ldots \ldots \ldots$

V. CASE STUDY: FAIRWINDS LNG RECEIVING

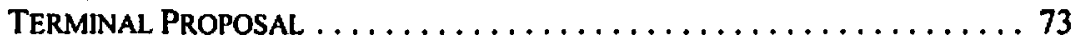

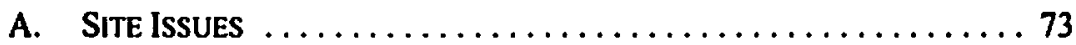

B. Terminalling SERVICES AgreEment $\ldots \ldots \ldots \ldots \ldots \ldots \ldots$

VI. Case Study: Qatar Petroleum $\ldots \ldots \ldots \ldots \ldots \ldots \ldots \ldots \ldots \ldots$

A. The State OF QATAR $\ldots \ldots \ldots \ldots \ldots \ldots \ldots \ldots \ldots \ldots, 77$

B. Qatar Petroleum ....................... 78

C. THE LNG INDUSTRY IN THE STATE OF QATAR $\ldots \ldots \ldots \ldots \ldots \ldots 78$

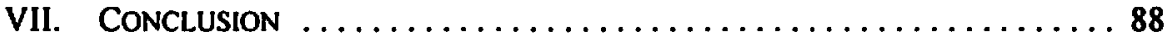

\section{INTRODUCTION}

Recently, liquefied natural gas (LNG) has risen from relative obscurity in North America to a position of high visibility. However, LNG has historically established a credible global position as a commercially sound, technologically safe and reliable component of the international trade in natural gas. It has developed as a means to move stranded gas from areas of excess supply to areas of no or limited access to indigenous natural gas production.

It has been predicted that significant growth in the LNG industry will not only continue, but will accelerate over the next ten years. This is no better evidenced than by noting the remarkable growth of LNG imports to the U.S. In 2002, U.S. imports of LNG accounted for 4 percent of the global LNG trade and equated to approximately 229 billion cubic feet (Bcf), or 4.8 million tons per annum (mtpa or approximately 630 million cubic feet per day (mmcf/d)). By 2003, U.S. imports of LNG were expected to reach approximately 540 Bcf (11 mtpa or approximately $1.5 \mathrm{Bcf} /$ day), more than doubling and representing approximately 2 percent of U.S. natural gas consumption. Furthermore, according to forecasts of the Energy Information Administration, U.S. LNG imports will experience an increase to more than 2.2 trillion cubic feet ( $\mathrm{Tcf}$ ( $46 \mathrm{mtpa}$ or approximately $6 \mathrm{Bcf} /$ day) in the year 2010 and constitute approximately 8 percent of U.S. natural gas consumption.'

U.S., Energy Information Administralion, Department of Energy, The Global Liquefied Natural Gas Markes: Status \& Outlook, DOE/ElA-0637 (Washington, D.C.: Department of Energy, 2003) at !, online: Energy Information Administration <www.eia.doe.gov/oiaf/analysispaper/globalpdf/eia_0637. pdß [Global LNG Market]. 
Our discourse on the subject of $L N G$ development is intended to provide the reader with an overview of the LNG industry and the various legal and regulatory issues that presently affect this industry. Part II of the paper includes a brief scientific explanation of the process involved in the creation of LNG, a short history of the development of the industry and a summary of the major producers of LNG. Part III sets out some of the current market conditions and issues, as well as the various North American projects currently in existence or in development. Part IV provides the reader with a review and analysis of the regulatory processes presently in effect or under consideration in both Canada and the U.S. Our discussion in Part $V$ sets forth a case study of an LNG project that was proposed by TransCanada PipeLines Limited and ConocoPhillips Company near the town of Harpswell, Maine, and outlines various siting, regulatory and commercial issues impacting the project. The article is concluded in Part VI with a second case study of the Qatargas and RasGas LNG projects in the State of Qatar.

\section{LNG BACKGROUNDER}

\section{A. What IS LNG?}

LNG is a form of natural gas that has been chilled sufficiently to become liquid in form. This liquid is clear, odorless and colourless and is considered to be non-corrosive and nontoxic. The LNG production and delivery process typically involves three steps. First, natural gas is transformed into a liquid through a complex cryogenic process, called liquefaction. To liquefy natural gas, impurities that would freeze such as water, carbon dioxide, sulphur and other various heavier hydrocarbons are removed. Following this removal, the gas is cooled to approximately -161 degrees Celsius (-256 degrees Fahrenheit) at atmospheric pressure. Liquefaction of natural gas results in a reduction in the volume of the gas by approximately 600 times, which creates a product that is far more economical to transport between continents, making this form of natural gas available throughout the world. ${ }^{2}$ The liquefaction process is expensive; however, in the last $\mathbf{4 0}$ years, technological developments have translated into an approximate 50 percent reduction in costs associated with liquefaction. As a result of these developments, the optimal size of a liquefaction unit (or train) has increased from 1 to $1.5 \mathrm{mtpa}$ to train sizes up to $7 \mathrm{mtpa}{ }^{3}$

The second step, which follows liquefaction of the gas, involves either storing the LNG in cryogenic holding tanks or pumping the LNG directly from the cooling vestibule into special insulated transportation vessels, such as trucks, tankers or railcars. Specially designed and insulated transport units are used to minimize product loss and to maximize safety. Technological developments in this area have resulted in the construction of significantly larger LNG tankers. The capacity of a typical state-of-the-art tanker is approximately 145,000 cubic metres of LNG; however, further size increases are in development, with capacities ranging from 160,000 cubic metres to slightly over 200,000 cubic metres. ${ }^{4}$

$2 \quad$ Ibid. at 3; Clingendael International Energy Programme (CIEP), The Role of Liquefied Natural Gas (LNG) in the European Gas Market, CIEP 03/2003 (The Hague: The Clingendael Institute, 2003) at 7, online: CIEP <www.clingendacl.nl/publications/2003/20030600_ciep_paper.pds?.

lbid. at 7

Ibid. at 8. 
The third step, once the vessel has reached its final destination, is to transfer the LNG into another cryogenic storage tank for later regasification and delivery, or to pump it directly into a regasification unit that uses sea water or air to reheat the LNG in order to transform it back into gaseous natural gas. ${ }^{5}$ Upon completion of this transformation, the natural gas is delivered into the existing pipeline grid for transportation and domestic consumption.

\section{B. A BRIEF HiSTORY Of THE GLOBAL. LNG INDUSTRY}

The scientific developments that resulted in the creation of the present-day liquefaction process began in the "19th century when British chemist and physicist Michael Faraday experimented with liquefying different types of gases, including natural gas... The first LNG plant was built in West Virginia [in the U.S.] in 1912. It began operation in 1917. The first commercial liquefaction plant was built in Cleveland, Ohio, in 1941."6

In January 1959, LNG transportation experienced a major development with the creation of the world's first LNG tanker, the Methane Pioneer. This experimental pilot project resulted in LNG cargo being carried from Lake Charles, Louisiana, to Canvey Island in the U.K. This pilot project successfully showed that large quantities of LNG could be transported by tanker across the open ocean.' Following the Methane Pioneer experiment, the British Gas Council commenced plans for a project to begin importing LNG from Venezuela to Canvey Island for commercial use. However, before the commercial agreements were executed, significant quantities of natural gas were discovered in Algeria. In 1964, as a consequence of this discovery, the U.K. became the world's first commercial LNG importer and Algeria the first commercial LNG exporter. ${ }^{8}$ Following this significant development, Algeria has remained as a major global player in the supply of LNG.

Subsequent to the developments in the U.K., four marine LNG importation terminals were constructed in the U.S. between 1971 and 1980 . These projects were initially quite successful; however, LNG imports subsequently declined due to increased gas discoveries in North America and LNG price disputes with Algeria. As a result, two of the American terminals closed and two suffered from very low utilization.

Then, in 1999, Trinidad commenced operation of the first LNG liquefaction plant in the western hemisphere (as opposed to an importation facility). Additionally, as a result of the recent increase in demand for natural gas in the U.S. and an increase in U.S. natural gas prices, two of the four U.S. marine terminals that were closed have been reopened. ${ }^{10}$

Ibid.

University of Houston Law Center, Institule for Energy, Law \& Enterprise (IELE). Introduction to LNG: An Overview on Liquefied Natural Gas (LNG), Is Properiies, the LNG Industry, Safety Considerations (Houston: University of Houston, 2003) at 10, online: IELE <www.energy.uh.edu/LNG/documents/ IELE_introduction_to_LNG.pdrs.

Ibid. at 10-11.

Ibid. at 11.

lbid.

Ibid. at 12 . 


\section{The Producers}

In the year 2002, a total of 12 countries exported $5.4 \mathrm{Tcf}$ (113 mtpa or approximately 14.8 Bcf/day) of natural gas as LNG, a significant increase from the year 1997, when nine countries shipped less than 4 Tcf (84 mtpa or approximately 11 Bcf/day)." "Global LNG liquefaction capacity is expected to increase from $6.6 \mathrm{Tcf}$ (139 million metric tons) [(approximately $18 \mathrm{Bcf} /$ day)] per year in 2003 to $9.4 \mathrm{Tcf}$ (197 million metric tons) [(approximately $25.7 \mathrm{Bcf} /$ day)] per year in 2007 , based on facilities currently under construction." 12

There are three major LNG producing regions in the world contributing to the LNG industry, namely: the Pacific Basin, the Middle East and the Atlantic Basin. ${ }^{13}$ The Pacific Basin is the world's largest LNG producing (and consuming) region having supplied 49 percent of all global LNG volumes in 2002. 14 The main producer in this region is Indonesia. The country is also the world's largest LNG producer, exporting approximately one-fifth of total global volume in 2002.15 The other major Pacific Basin LNG producers are Malaysia, Australia and Alaska. Malaysia, the third largest LNG exporter, exported $741 \mathrm{Bcf}$ (15.6 mtpa or approximately 2 Bcf/day) of LNG in 2002. As a result of its Northwest Shelf project, Australia exported $367 \mathrm{Bcf}(7.7 \mathrm{mtpa}$ or approximately $1.0 \mathrm{Bcf} /$ day) of LNG in 2002 and continues to develop its export capacity with the recent commencement of construction of additional trains. ${ }^{16}$

"Middle Eastern LNG production began with the Das Island plant in Abu Dhabi in 1977. New capacity in Qatar and Oman developed between 1996 and 2000 and capacity expansions at Das Island significantly increased LNG production in the Middle East."17 By 2002, producers in this region were exporting approximately 23 percent of all global exports. ${ }^{18} \mathrm{By}$ late 2003, the three Middle Eastern exporters - Qatar, Oman and Abu Dhabi — had 1.4 Tcf (29 mtpa or approximately $3.8 \mathrm{Bcf} / \mathrm{day}$ ) of annual capacity and it is anticipated that expansions to liquefaction facilities in Oman and Qatar will contribute an additional $619 \mathrm{Bcf}$ (13 mtpa or approximately $1.7 \mathrm{Bcf} /$ day) of annual capacity, resulting in a total of $2.0 \mathrm{Tcf}$ (42 mtpa or approximately $5.5 \mathrm{Bcf} /$ day) of annual Middle East capacity by 2007 . Qatar presently ranks fourth in global LNG exports with a present annual LNG capacity of $726 \mathrm{Bcf}$ (14.4 mtpa or approximately $2.0 \mathrm{Bcf} /$ day). As will be discussed later in this article, the country enjoys immense natural gas reserves and low upstream production costs. As a result, Qatar has the potential to greatly expand its LNG exports. Oman's present annual capacity is 356 Bcf (7.3 mtpa or approximately $1.0 \mathrm{Bcf} /$ day)..$^{19}$

Global LNG Market, supra note I at 6.

Ibid. at I.

Andy Flower \& Richard King. LNG Today: The Promise and the Pilfalls (Oxford: The Energy Publishing Network, 2002) at 3, online: The Energy Publishing Network Shop <www.shop.energy publishing.com/downloads/LNG-exec-sum.pdß>. 
"The Atlantic [B]asin covers LNG production facilities on both sides of the Atlantic as well as North African LNG facilities on the Mediterranean." ${ }^{20}$ In 2002, the Atlantic Basin exporters produced $1.5 \mathrm{Tcf}$ ( $32 \mathrm{mtpa}$ or approximately $4.1 \mathrm{Bcf} /$ day) of LNG, constituting approximately 29 percent of all global LNG exports. ${ }^{21}$ There is an emphasis on LNG development in this region, evidenced by the fact that by the end of 2003 Atlantic Basin LNG exporters' annual capacity was approximately $2.1 \mathrm{Tcf}$ (43 mtpa or approximately 5.7 Bcf/day). Extensive development is projected in many countries included in the Atlantic Basin such as Nigeria, Trinidad and Tobago, Egypt and Norway. As a result, capacity in this region should increase to approximately $3.3 \mathrm{Tcf}$ ( $73 \mathrm{mtpa}$ or approximately $9.0 \mathrm{Bcf} /$ day) by 2007.22

The largest LNG producing country in the Atlantic Basin is Algeria, which was also recognized as the second largest global $L N G$ exporter in the year 2002, having exported 935 Bcf (19.6 mtpa or approximately $2.5 \mathrm{Bcf} / \mathrm{day})$ of LNG. Nigeria, another significant contributor, exported $394 \mathrm{Bcf}(8.2 \mathrm{mtpa}$ or approximately $1.0 \mathrm{Bcf} /$ day) of LNG in 2002 and has begun construction of two additional trains, scheduled to begin operations in 2005. Trinidad and Tobago has also enjoyed significant development with a present annual capacity of $482 \mathrm{Bcf}$ (9.9. mtpa or approximately $1.3 \mathrm{Bcf} / \mathrm{day})$ from the country's single three train LNG facility. This is up from the 189 Bcfr of LNG exported in 2002. In the spring of 2003, construction of a fourth train was approved, which should provide Trinidad and Tobago with an additional $253 \mathrm{Bcf}(5.2 \mathrm{mtpa}$ or approximately $700 \mathrm{mmcf} / \mathrm{day})$ annually. ${ }^{23} \mathrm{~A}$ future contributor to the LNG industry in the Atlantic Basin region is Norway, which is presently constructing a liquefaction terminal in the Norwegian Sea. Commencing in 2006, Norway intends to export approximately $200 \mathrm{Bcf}(4.1 \mathrm{mtpa}$ or approximately $550 \mathrm{mmcf} /$ day) of LNG annually. ${ }^{24}$

\section{NORTH AMERICAN CONTEXT}

\section{A. Current Supply and Demand - The Growing LNG Wedge}

Historically, North America has been the exception to LNG development. Globally, the concept of LNG importing has been embraced, particularly by Japan, South Korea and many European nations; however, LNG has been slow to reach North American markets. The reason for this trend is, until recently, the presence of abundant American and Canadian natural gas, which has kept North American gas prices low. In the past, North American drilling activity has responded quickly and efficiently to market signals and has been able to readily meet the market demands. ${ }^{25}$ As a result, there has been a lack of incentive to develop and/or purchase higher priced LNG. However, Canadians and Americans alike have recently recognized that natural gas shortfalls could significantly impact economic conditions in North

Flower \& King, supra note 13 at 3.

Global LNG Market, supra note 1 at 14.

Ibid.

Ibid.

lbid. at 15.

National Petroleum Council, Committee on Natural Gas, Balancing Natural Gas Policy: Fueling the Demands of a Growing Economy. Summary of Findings and Recommendations, vol. 1 (Washington. D.C.: National Petroleum Council, 2003) at 17, online: National Petroleum Council <www.npc.org>. 
America. "It now appears ... that natural gas productive capacity from accessible basins in the United States and Western Canada has reached a plateau." ${ }^{26}$ The National Petroleum Council has observed that "[r]ecent experience shows steeper decline rates in existing production and a lower average production response to higher prices from new wells in these areas. This trend is expected to continue."27 Markets appear to have tightened to a degree not seen in recent periods and prices have increased significantly. The combination of this tightening of supply and resulting higher natural gas prices, lower LNG production costs and the desire for intemational gas producers to monetize their gas reserves has resulted in a bullish outlook for the LNG business in the foreseeable future. ${ }^{28}$

In June 2003, U.S. Federal Reserve Chairman, Alan Greenspan, wamed of the potential effects of shortfalls in North American gas supplies and publicly endorsed proposals to build LNG facilities to stabilize gas prices. ${ }^{29}$ As a result, LNG has become the fastest growing segment of the North American gas business. As previously noted, the amount of LNG imports is forecasted to increase dramatically in the U.S. by the year $20100^{30}$

\section{B. NORTH AMERICAN ProjeCtS}

As stated earlier, there are presently four LNG import terminals in the continental U.S., namely:

1. Cove Point, Maryland

Storage Capacity: 5.0 Bcf

Regasification Capacity (Peak): 365 Bcf per year (1.0 Bcf/day)

2. Elba Island, Georgia

Storage Capacity: 4.1 Bcf

Regasification Capacity (Peak): 246 Bcf per year (674 mmcf/day)

3. Everett, Massachusetts

Storage Capacity: $3.5 \mathrm{Bcf}$

Regasification Capacity (Peak): 260 Bcf per year (712 mmcf/day)

4. Lake Charles, Louisiana

Storage Capacity: 6.3 Bcf

Regasification Capacity (Peak): 365 Bcf per year (1.2 Bcf/day) ${ }^{31}$

I..

t7

2*

Ibid. at 18-20.

Alan Greenspan, "Testimony of Chairman Alan Greenspan: Natural gas supply and demand issues" (Testimony before the the Committee on Energy and Commerce, U.S. House of Representatives, 10 June 2003), online: The Federal Reserve Board <www.federalreserve.gov/boatddocs/lestimony/2003/ 20030610/default.htm>.

Ibid. at 26. 
The combined peak capacity of the four U.S. LNG import terminals in existence is approximately $1.2 \mathrm{Tcf}$ annually ( $26 \mathrm{mtpa}$ or approximately $3.5 \mathrm{Bcf} / \mathrm{day}$ ). All of these terminals have either recently completed an expansion or intend to do so by the year $2006 .{ }^{32}$

The U.S. Department of Energy has stated that currently there are, at a minimum, two dozen proposals to construct new LNG regasification facilities in North America. The Department has predicted that by 2010 , terminals could be located along the U.S. and Canadian east coasts, Mexico's west coast, the Gulf of Mexico, the Bahamas and offshore of the U.S. west coast. ${ }^{33}$

In Canada, with respect to LNG facilities, a proposal has been submitted by Irving Oil Limited to construct and operate an LNG receiving facility near Saint John, New Brunswick. In addition, terminals have been proposed in locations near Point Tupper, Nova Scotia, the St. Lawrence area of Quebec and in British Columbia.

\section{COMMERCIAL ISSUES}

It has been stated that the business model for the LNG industry has basically remained unchanged for the last 30 years. However, in recent years, it appears that the LNG industry has been developing a new commercial structure. ${ }^{34}$ Furthermore, the development of LNG trade has differed in the varying global regions engaged in the industry. Prime examples of this are the distinct evolutions of the LNG markets in the Atlantic and Pacific Basins, which continue to affect the terms of contracts, means of pricing and import volumes in the regions. The two regions vary in that the countries in the Atlantic Basin use both domestically produced natural gas and pipeline imports and LNG to meet their natural gas demands, while countries in the Pacific Basin are almost entirely dependent upon $\mathrm{LNG}{ }^{35}$

The LNG industry has been historically predicated upon long-term sales contracts of 20 years in duration, which typically included take-or-pay commitments at about 90 percent of contractual quantities and which were usually entered into prior to the development of an LNG project. This was to provide the producer/supplier with protection from volume risk and to provide security for the recovery of the extensive upfront investment costs associated with a large-scale project. ${ }^{36}$ In addition, according to the Groupe International des Importateurs de Gaz Liquefie, contracts resulting in the sale of approximately $30 \mathrm{mtpa}$ of LNG per year to Asian countries will expire within the next ten years." One can expect significant changes in the terms of contracts covering this Asian LNG supply as a result of recent developments in the LNG market, which is now supporting increased flexibility. The take-or-pay commitments, prevalent in previous LNG sale agreements, are starting to become less common. ${ }^{38}$ 
Furthermore, as a result of greater flexibility in LNG shipping resulting from both more producing locations and more available tankers, there has been an increase in short-term sales contracts. ${ }^{39}$ It is also noteworthy that buyers and sellers of $L N G$ have been appropriating new roles, whereby certain sellers of LNG have leased available tankers and regasification terminal capacity and appear to be extending their involvement in the industry into LNG trading. Buyers have been investing in the upstream market, including liquefaction plants. ${ }^{40}$ A further significant development in the LNG market has been the growth of the spot market (that is those LNG sale agreements entered into for periods of 12 months or less). This market has grown from being non-existent only a few years ago. It is anticipated that this portion of the larger market will continue to grow as a result of uncommitted production capacity from the construction of new plants, market demand for additional LNG, greater transport availability and greater contract flexibility. ${ }^{41}$ It is projected that spot trading may eventually reach 15 to 20 percent of LNG imports in the course of the next ten years. ${ }^{42}$

The structuring and expansion of LNG facilities (both the liquefaction and regasification facilities) will be influenced by which party will bear the risk of any decline in the market price of natural gas during the life of the project. This will affect both the financing for the construction and expansion of the project and the duration of the terminal services agreements that underpin the project.

In addition, the extent of reductions and cost efficiencies in the LNG value chain, including the cost and capacity of ships, liquefaction plants, and regasification and storage terminals, will influence whether LNG can remain price competitive with pipeline natural gas. While the Gas Technology Institute estimates that liquefaction costs have decreased approximately 35 to 50 percent over the past ten years (including the reduction of liquefaction costs from US\$500 per ton of annual liquefaction capacity to US\$200 per ton, and the reduction of building costs of LNG tankers from US\$280 million to US\$155 million since the mid 1980s), ${ }^{43}$ competing cost reductions and efficiencies in pipeline delivery, coupled with increased supply of Alaskan and McKenzie Valley gas in the long-term, may impact the relative competitiveness of LNG costs.

\section{REGULATORY ISSUES}

LNG regulation in North America primarily focuses on environmental concerns and the health and safety of communities surrounding LNG regasification terminals and storage facilities. In this section, we first outline Canadian regulation of LNG, particularly in Nova Scotia and British Columbia, where LNG projects have been proposed or are likely to arise in the near future. Second, we provide a brief overview of U.S. regulation of LNG. Given that LNG terminals have operated in the U.S. for a number of decades, U.S. regulation and law is more developed than Canadian law in this area.

Jbid. at 30, 32.

Ibid. at 32 .

lbid. at 40 .

lbid.

lbid. at 42 . 
To date, Canadian regulations have been based on U.S. standards, a trend that we expect will continue as LNG projects develop in Canada. At a recent North American energy conference, a representative of the National Energy Board (NEB) stated that the Mexican, U.S. and Canadian energy regulators have signed an Informal Agreement on Cooperation, which reflects the desire of the NEB, the U.S. Federal Energy Regulatory Commission (FERC) and the Mexican authorities to share information and endeavour to provide compatible regulatory approaches. Regulators recognize that investment decisions are based in part on the regulatory process required to build LNG terminals. According to the NEB, this forum shopping has driven the harmonization of North American regulation. ${ }^{44}$

\section{A. Canadian Regulation of LNG}

The overview of Canadian regulations involves both jurisdictional and substantive aspects and is discussed in three parts. First, the constitutional and hence jurisdictional issues particular to LNG project regulation are outlined. The division of federal and provincial legislative power depends on the stage of the LNG process; namely, natural gas production, liquefaction, transportation, regasification and distribution. Second, the current standards for LNG production, storage and handling, which are based primarily on regulations set by the Canadian Standards Association, are discussed. Finally, environmental regulation and assessment processes required in the LNG industry are described.

Each of these regulatory aspects of LNG is an important consideration when assessing jurisdictional issues and risk allocation in LNG contracts, joint ventures or transportation agreements.

\section{JURISDICTION OVER LNG PROJECTS}

The Constitution Act, $1867^{45}$ grants authority over natural resource issues to both the federal and provincial governments. Generally speaking, the federal government has constitutional jurisdiction over the transportation of energy interprovincially and internationally, while the provinces have authority over the development and production of energy within the province.

In relation to $\mathrm{LNG}$, the authority to regulate depends on the stage of the LNG process. In Canada, the proposed LNG projects in Nova Scotia and British Columbia relate to the import and regasification of LNG. As such, the following discussion focuses on these processes. However, the liquefaction and export of LNG would be similarly regulated.

"Carmen Dybwad, "Energy Trade and Transportation: Conscious Parallelism" (Speech to the International Association for Energy Economics (IAEF), North American Conference, 20 October 2003), online: National Energy Board <www.neb-one.gc.ca/newsroom/speeches/cdenergytrade transportationiaee2003_10_20_e.htm>.

ts Consfitustion Act. $186 \overline{7}$ (U.K.K.), $30 \& 31$ Vict., c. 3, reprinted in R.S.C. 1985, App. II, No. 5 [Consritution]. 


\section{a. Transportation of LNG into Canada}

The shipment of LNG into Canada is regulated by the federal government, which has jurisdiction over navigation and shipping pursuant to s. 91(10) of the Constitution. The Canada Shipping $A c{ }^{A 6}$ regulates ship safety and pollution prevention and gives effect to intermational shipping conventions. This legislation grants regulatory oversight of LNG ships to the Canadian Coast Guard. In addition, the Canada Shipping Act designates pollution prevention officers to control and contain coastal spills.

The federal government also regulates shipments under the Canada Marine $A c t .{ }^{47}$ Under this $A c t$ 's related regulations - the Port Authorities Operations Regulations ${ }^{48}$ - a port authority may give authorization (for an applicable fee) to carry out an LNG transfer. In providing its authorization, the port authority may also prescribe the insurance coverage or damage security required to complete an LNG transfer. The form of authority depends on the location of the port. For example, in the British Columbia ports (such as Fraser River, Nanaimo, North Fraser), authorization is provided by posting a sign or in written form in a prominent place that is clearly visible to persons that want to conduct the activity; ${ }^{49}$ in Halifax, the port authority must give individual authorization to a company. ${ }^{50}$

Federal laws also address alterations to navigable waters and fisheries, activities that by necessity will occur in the construction of an LNG regasification facility. Under Part l of the Navigable Waters Protection Acl," any "work" that is placed on, over, under, across or through navigable waters must be approved by the Minister of Transport. "Work" is defined as

(a) any bridge, boom, dam, wharf, dock, pier, tunnel or pipe and the approaches or other works necessary or appurtenant thereto,

(b) any dumping of fill or excavation of materials from the bed of a navigable water,

(c) any telegraph or power cable or wire, or

(d) any structure, device or thing, whether similar in character to anything referred to in this definition or not, that may interfere with navigation. $\$ 2$

This broad definition would include an LNG receiving facility, which typically requires a large dock or wharf to accommodate the LNG tankers and which may also require dredging in the construction of the wharf to allow for large tankers. If the LNG shipment will alter or disrupt a fish habitat, the LNG importer must obtain authorization under s. 35(2) of the Fisheries $\mathrm{Act}^{53}$ from the Ministry of Fisheries and Oceans. Additionally, the LNG importer must comply with federal environmental regulations when shipping LNG, which are addressed in more detail below.

S.C. 1998 , c. 10.

S.O.R./2000-55.

Jbid., s. 25.

Ibid, s. 27.

R.S.C. 1985 , c. N-22, s. 5.

Ibid., s. 3.

R.S.C. 1985, c. F-14. s. 35(2). 


\section{b. Regasification and Storage}

A regasification facility or storage terminal located onshore would likely be regulated by the provincial government, pursuant to s. 92(13) of the Constitution, which grants the province jurisdiction over property and civil rights in the province.

In British Columbia, gas facilities are regulated by the Oil and Gas Commission $\mathrm{Act}^{54}$ and the Pipeline Regulation." Only the Pipeline Regulation directly addresses LNG facilities. According to s. 12, LNG facilities that are part of a pipeline must comply with the Canadian Standards Regulation CSA Z276, which is described in more detail below. The British Columbia Oil and Gas Commission is responsible for issuing permits under the Oil and Gas Commission Act.

In addition, an LNG facility may require a certificate of public convenience and necessity under the Utilities Commission Act ${ }^{56} \mathrm{~A}$ company that owns or operates facilities for the storage of "petroleum and petroleum products" for the public or a corporation for compensation is a "public utility" under the UCA, subject to certain exceptions for the petroleum industry. ${ }^{57}$ It is not clear whether LNG falls within the definition of "petroleum" or "petroleum products"; nonetheless, companies have regarded LNG facilities as a public utility in the past. A recent example is Terasen Gas Inc., which has stated that it will seek approvals from the British Columbia Utilities Commission for its proposed LNG facility on Vancouver Island. ${ }^{\text {s8 }}$

In Nova Scotia, gas facilities (including an LNG import terminal) are regulated by the Gas Plant Facility Regulations. ${ }^{59}$ According to ss. 6 and 7, a company must obtain a permit to construct a gas facility and a licence to operate it. The terms and conditions of receiving a permit or licence depend on compliance with the Energy and Mineral Resources Conservation Act, ${ }^{60}$ the Pipeline $A c t,{ }^{61}$ any regulations or designs approved by the Nova Scotia Utility and Review Board, laws of general application (for example, environmental laws) and any applicable industry codes or standards.

Again, a company that operates an LNG facility may also require permits as a "public utility," defined in the Nova Scotia Public Utilities ACt as follows:

"public utility" includes any person that may now or hereafter own, operate, manage or control ... any plant or equipment for the production, transmission, delivery or furnishing of electric power or energy, water or steam heat either directly or indirectly to or for the public. ${ }^{62}$

S.B.C. 1998 , c. 39.

B.C. Reg. 360/98, passed pursuant to the Petroleum and Natural Gas Act, R.S.B.C. 1996, c. 361. R.S.B.C. 1996, c. 473, s. $45[U C A]$.

Jbid., s. I.

Westland Resources Group Inc., Terasen Gas (Vancouver /sland) Inc. Liquefied Natural Gas Facility: Environmenial and Social Review (Westland Resources Group Inc., 2004) at 19, online: Terasen Gas <www.terasengas.com/AboutTerasenGas/PipelinesandFacilities/LNGStorageProject/Reports.htm> N.S. Reg. 149/2001.

R.S.N.S. 1989, c. 147, s. 5: S.N.S. 2000 , c. 12, s. 2.

R.S.N.S. 1989 , c. 345.

R.S.N.S. 1989 , c. 380 , s. 2(e)(iv) 
An LNG facility is not expressly included as a public utility, but this definition is likely broad enough to encompass LNG facilities.

LNG terminals may fall under federal jurisdiction in certain circumstances. The National Energy Board (NEB) has jurisdiction over interprovincial or offshore storage facilities under the National Energy Board Act, ${ }^{63}$ namely, in the definition of pipeline:

\begin{abstract}
"pipeline" means a line that is used or to be used for the transmission of oil, gas or any other commodity and that connects a province with any other province or provinces or extends beyond the limits of a province or the offshore area as defined in section 123, and includes all branches, extensions. tanks, reservoirs, storage facilities, pumps, racks, compressors, loading facilities, interstation systems of communication by telephone. telegraph or radio and real and personal property and works connected therewith, but does not include a sewer or water pipeline that is used or proposed to be used solely for municipal purposes. ${ }^{64}$
\end{abstract}

To date, no offshore LNG receiving terminals have been proposed in Canada. Bilateral offshore agreements would also have an effect on regulation in this area. ${ }^{.5}$

The NEB may also assume jurisdiction over gas facilities (which likely includes LNG terminals) pursuant to the Supreme Court of Canada's decisions in Westcoast Energy Inc. $v$. Canada (National Energy Board) ${ }^{66}$ and United Transportation Union v. Central Western Railway Corp. ${ }^{67}$ If a facility is functionally integrated and managed in common with a federal work or undertaking (such as an interprovincial pipeline), or if the undertaking is essential, vital and integral to a federal undertaking, the NEB would take jurisdiction under the National Energy Board Act ${ }^{68}$ In Westcoast, the Court decided that a processing plant facility could fall under federal jurisdiction because it formed part of a single federal undertaking. However, according to Central Western, different aspects of the undertaking must share a sufficient operational connection to bring everything connected with that industry under federal jurisdiction. A close commercial relationship is not sufficient; there must also be some degree of common control and dependence. In the authors' view, an LNG terminal project proponent should have a strong argument to resist the implications of Westcoast.

The trend in the U.S. is for local communities and municipalities to become actively involved in the approval process of LNG facilities. ${ }^{69}$ If this type of involvement becomes a trend in Canada, the provincial and municipal governments are unlikely to relinquish control to the NEB. In all likelihood, the NEB will regulate very limited aspects of the LNG industry in Canada.

R.S.C. 1985, c. N-7.

lbid., s. 2 [emphasis added].

For example, the Canada-Nova Scotia Offshore Petroleum Resources Accord Implementation Act. S.C. 1988, c. 28.

[1998] I S.C.R. 322 [Wesicoast].

[1990] 3 S.C.R. 1112 [Central Western].

Supra note 63.

See discussion of U.S. regulation of LNG below. 


\section{c. Transportation from Storage Facility}

The regulation of LNG distribution will depend on where the gas is transported. Interprovincial and international pipelines are works or undertakings that fall exclusively within federal jurisdiction. According to Westcoast, any pipeline that extends beyond the boundaries of a province falls within federal jurisdiction. However, notwithstanding that LNG will be transported either interprovincially or internationally, and hence the federal government will regulate these pipelines, it is anticipated that this jurisdiction will not extend to the actual LNG terminal and any interconnect feeder pipeline that simply ties the LNG facility into an existing pipeline.

Canadian regulators may refer to the U.S. authorities on this point. As described in detail below, the FERC's policy is to treat an LNG terminal as a source of. production rather than as a component of the gas transportation system. ${ }^{70}$

\section{LNG STANDARDS}

As noted above, the regulation of the LNG industry primarily focuses on public safety and the environment. Industry standards (described below) address the safety issues, while regulations and assessments (described in the next section) concentrate on pollution and other environmental effects of $L N G$.

The main safety concern is the potential for an LNG spill that results in a fire. To respond to this risk, LNG regulation is driven by three safety concerns, which may be summarized as follows:

1. Containment of Leaks and Spills. The industry is responsible for containing LNG by using suitable materials for storage tanks, pipelines and facilities and appropriate engineering design throughout the liquefaction or regasification process.

2. Operational and Emergency Systems. LNG operations must use gas, liquid and fire detection to identify leaks or spills, and automatic shut-off systems to respond to leaks or spills. Operational procedures and emergency response policies also prevent harm.

3. Separation Distances. Industry codes and regulations require that there are safe buffer distances between individual elements of an LNG facility, and between an LNG facility and adjacent property."

In Canada, these three concerns are addressed through industry standards set by the Canadian Standards Association (CSA) in CSA Z276-01: "Liquefied Natural Gas (LNG) Production, Storage and Handling." This CSA code incorporates by reference a number of American standards; in particular, standards promulgated by the American Petroleum Institute, American Gas Association and National Fire Prevention Association.

ro

See the FERC's decision in Hackberry I.NG Terminal, L.L.C., 101 F.E.R.C. $\$ 61,294$ (2002), discussed further below.

31

See also University of Houston Law Center, Institute for Linergy, Law and Enterprise (IELE), LNG Safety and Security (Houston: University of Houston, 2003) at 6, 10-1I, online: <www.energy. uh.edu/LNG/documents/IELE_I.NG_Safely_and_Security.pdß $\$$. 
CSA Z276-0I focuses on seven areas of safety regulation:

1. The strength and suitability of materials that come into contact with LNG;

2. The reliability of systems for preventing overpressurization, vacuum conditions or other malfunctions in vessels, piping and equipment containing LNG;

3. Passive features incorporated into the terminal to limit the consequences of a given accident (such as separation distances between the individual elements of an LNG facility, and minimum spacing criteria between the facility and outside property);

4. Systems for the detection of fire and explosion hazards;

5. Provision of emergency shutdown for the terminal;

6. Active systems for suppression of fires and the reduction of vapour cloud hazard; and

7. Training of terminal personnel.

The Canadian Standards Association regularly reviews its standards to incorporate the most up-to-date industry requirements. The most recent amendment to CSA Z276-01 was made in 2001.

As mentioned, CSA Z276-01 has been adopted by Canadian regulators pursuant to federal and provincial regulations. In British Columbia, the Pipeline Regulation requires compliance with CSA Z276-01 for pipelines transporting LNG. ${ }^{2}$ In Nova Scotia, the Energy and Mineral Resources Conservation $A c t$, requires compliance with any applicable industry codes or standards, which would include CSA Z276-01. ${ }^{73}$ Finally, the federal Onshore Pipeline Regulations require compliance with CSA Z276-01 for any LNG pipelines. ${ }^{74}$

\section{ENVIRONMENTAL REGULATION}

Over the past decade, environmental reports, permits and assessments have become noteworthy statutory obligations imposed on the oil and gas industry. Environmental concerns include general concerns for noise, air and water pollution, as well as site-specific effects on wildlife habitats, ecosystems and aesthetics.

Companies involved in a large scale project such as an LNG terminal will have to conduct an environmental assessment in addition to any other provincial and federal approvals, permits or licences. In practice, these approvals and permits are often obtained during the course of an environmental assessment and requirements are coordinated to the extent possible.

As a result of the overlapping jurisdiction between the federal and provincial governments, proposed LNG projects could be subject to two levels of environmental review. This section of the article will focus on the federal and provincial environmental regulations and the possibility of a joint review process between federal and provincial authorities. 


\section{a. Federal Legislation}

A project that touches on an area of federal jurisdiction is subject to the Canadian Environmental Assessment Act. ${ }^{\text {'s }}$ An environmental assessment is a process used by the government to identify any adverse environmental effects of proposed projects and to ensure the mitigation of such effects where possible. ${ }^{76}$

The CEAA applies to "projects" that involve a federal authority. LNG projects may potentially involve approval of federal authorities, most possibly with respect to transporting LNG into and throughout Canada.

The proponent of an LNG project must prepare and submit a project description to the responsible federal authorities (such as the NEB, Minister of Transport or Minister of Fisheries and Oceans). The federal government will then determine the responsible authority in accordance with the Federal Authorities Regulations. ${ }^{78}$

The federal authority responsible for the assessment will identify the type of environmental assessment (for example, a screening, comprehensive study, mediation or review panel). Most federal projects simply involve a screening, which involves an analysis of available information about the environmental effects of a proposed project. Screenings vary in time, length and depth of analysis, depending on the circumstances of the proposed project, the existing environment and the potential environmental effects.

Large-scale projects with the potential for significant adverse effects on the environment typically require a comprehensive study. According to the Comprehensive Study List Regulations, ${ }^{79}$ a comprehensive study is required for certain LNG facilities, specified as follows:

13. The proposed construction, decommissioning or abandonment, or an expansion that would result in an increase in production capacity of more than 35 per cent of ...

(d) a facility for the liquefaction, storage or regasification of liquefied natural gas, with a liquefied natural gas processing capacity of more than $3,000 \mathrm{vd}$ or a liquefied natural gas storage capacity of more than $50,000 \mathrm{i}$.

In a comprehensive study, a certified environmental practitioner identifies the potential environmental effects and the measures to mitigate those effects. ${ }^{80}$ The findings are presented in a written report to the Minister of Environment, who ultimately approves or declines the project. Public participation in the comprehensive study is mandatory and any public input

S.C. 1992 , c. 37 [CEAA].

Jbid.

See for example, any physical work listed in the Inciusion List Regulations. S.O.R.194-637.

S.O.R. $196 \cdot 280$.

S.O.R./94-638.

In Canada, professionals in this area are certified as a Canadian Certified Environmental Practitioner (CCEP) if they have at least five years of relevant work experience and demonstrate competency that meets or exceeds Canada's National Occupational Standards. See description online: Canada's National Certifications for Environmental Practitioners <www.cecab.org/CCEP.asp>. 
must be considered by the Minister of Environment. In addition to the comprehensive study, the Minister may refer the issue to a mediation or review panel between all interested parties. $^{81}$

Currently, a Canadian LNG project is undergoing the federal environmental assessment process. Irving Oil Limited submitted a proposal on 6 February 2002 to construct and operate an LNG receiving, storage and processing facility near Saint John, New Brunswick. ${ }^{82}$ Fisheries and Oceans Canada has been appointed as the federal responsible authority and is presently preparing a comprehensive study report. In contrast, the Access Northeast project in Nova Scotia filed for a screening on 4 November $2003 .{ }^{33}$

\section{b. Provincial Legislation}

Provincial environmental legislation will apply when an LNG project affects land and resources within a province. For example, a proposed onshore LNG terminal will be subject to the provincial environmental assessment process.

In British Columbia, LNG projects may be reviewed pursuant to the Environmental Assessment Act. ${ }^{\text {s4 }}$ The B.C. Environmental Assessment Office(EAO) coordinates assessment of the environmental, economic, social, heritage and health impacts of major development proposals within the province. Prior to 1995, major projects in B.C. were reviewed under separate processes managed by numerous authorities depending on the project sector. Under the present legislation, the EAO coordinates all environmental assessments. However, the Ministers responsible for a particular project (the Minister of Energy and Mines, for example) will have the ultimate approval of a project based on its overall acceptability. ${ }^{85}$

All projects that meet the criteria set out in the Reviewable Projects Regulation ${ }^{36}$ must undergo the assessment process. According to Part 4 of this Regulation, natural gas processing plants and storage facilities are subject to environmental assessment if the facility exceeds 3 petajoule $(\mathrm{PJ})$ per year. Presumably, LNG facilities would also be subject to an assessment, although the Reviewable Projects Regulation does not expressly include LNG. Following the environmental assessment, the appropriate minister will issue an environmental assessment certificate if the project is approved.

CEAA, supra note 75, ss. 16, 21.21 .1$.

*2 For more information, sec Minister of the Environment and Local Government for the Province of New Brunswick and Fisheries and Oceans Canada. Final Guidelines for an Environmental Impact Assessment Liquefied Natural Gas Receiving. Storage and Processing Facility (Final Guidelines issued to Irving Oil Limited. 25 March 2002), online: Governınent of New Brunswick <www.gnb.ca/0009/ 0377/0002/tinal-e.pdis. 


\section{(ii) Nova Scotia}

In Nova Scotia, an LNG proposal will be reviewed by the Nova Scotia Environmental Assessment Board pursuant to the Environment Act. ${ }^{87}$ The Nova Scotia process applies to all "developments" listed in the regulations, which are classified as "Class I" developments (which require less onerous assessments) and "Class 2" developments. According to the Environmental Assessment Regulations, ${ }^{88}$ "[a] storage facility with a total capacity of over $5,000 \mathrm{~m}^{3}$ intended to hold liquid or gaseous substances" ${ }^{139}$ is a Class 1 development. Therefore, an LNG storage facility alone could fall into the former category. However, a regasification plant would likely be a Class 2 development. Class 2 undertakings require an environmental assessment report and formal public review, which may include hearings. ${ }^{90}$

The Nova Scotia Environmental Assessment Board suggests that a Class 2 assessment typically takes up to 275 days to complete. An assessment may be reviewed by any member of the general public, interest groups and government departments and agencies, including the Departments of Natural Resources, Environment and Labour, or Agriculture and Fisheries."

\section{c. Joint Review}

As mentioned, a project may be subject to both the $C E A A$ and provincial environmental assessment legislation. A number of provinces, including Manitoba, Saskatchewan, Alberta and British Columbia, have signed cooperative agreements with the federal government so that projects subject to dual regulation are assessed under one environmental assessment.

In other provinces, including Nova Scotia, provincial and federal governments cooperate informally or on a project-by-project basis to coordinate environmental assessment processes. For example, the federal Minister of Environment and the Nova Scotia Minister of Environment and Labour signed an agreement to conduct a joint environmental review of the basalt quarry, processing facility and marine terminal (the Whites Point Quarry Project) in Digby, Nova Scotia. ${ }^{92}$ Nova Scotia is permitted to enter into such an agreement pursuant to s. 48 of the Environment Act. Cooperation agreements should set out the parties to the agreements (for example federal and provincial agencies), a timeline to develop the cooperative processes and the procedure to follow in any assessment and review hearings. From an industry perspective, timing is particularly important, as any prolonged delay in the assessment process could result in lost opportunities or projects. ${ }^{93}$

S.N.S. 1994-95, c. I.

N.S. Reg. 26/95, as am. by N.S. Reg. 44/2003.

Ibid., Sch. A.

Ibid., s. 11

See Nova Scotia, Environment and Labour, Environmental Assessment: Frequently Asked Questions, online: Nova Scotia Environment and Labour <www.gov.ns.ca/enla/ess/ea/faqs.htm>.

For a copy of this agreement, sec online: CEAA <www.ceaa-acee.gc.ca/010/0001/0001/0023/draft_e. htm>.

" Judith Hanebury, "Cooperative Environmental Assessments: Their Increasing Role in Oil and Gas Projects" (2001) 24 Dal. L.J. 87 at 97. 


\section{B. AMERICAN REgulation OF LNG}

In the U.S., the primary regulators of the LNG facilities are the FERC, the federal Department of Energy (DOE), the Department of Transportation (DOT), the U.S. Coast Guard (USCG) and the Maritime Administration. ${ }^{94}$

The DOE monitors the import and export of LNG and requires shippers of LNG to obtain import authorization from the DOE's Office of Fossil Energy in order to deliver LNG into the U.S. The shippers are responsible for arranging delivery of the LNG to the terminal. ${ }^{\text {95 }}$ In addition to traditional maritime legislation, shippers are also subject to the jurisdiction of the USCG in relation to the design, construction, manning and operation of LNG ships and barges under the Port and Tanker Safety Act of $1978 .{ }^{36}$

The jurisdiction over licensing, siting, construction and operation of LNG facilities is divided between the DOT and the FERC depending on whether the LNG facility is considered to be a "Deepwater Port" located beyond State boundaries. ${ }^{97}$ In November 2002, Congress enacted The Maritime Transportation Security Act, ${ }^{98}$ which amended the Deepwater Port Act, and expanded the definition of "Deepwater Port" to include natural gas deepwater ports such as LNG terminals. ${ }^{100}$ This amendment conferred to the DOT jurisdiction over LNG facilities that are constructed offshore in federal waters. The MTSA also enlarged the USCG's authority with regard to port security, including transportation of LNG into maritime ports. The DOT has delegated the authority to grant licences to construct and operate deepwater LNG facilities to the USCG and the Maritime Administration.

Notwithstanding the DOT's recent exercise of jurisdiction over certain offshore LNG facilities as deepwater ports, the regulation of construction and operation of LNG facilities has historically been governed by the FERC and its predecessor, the Federal Power Commission, pursuant to the Natural Gas Act. ${ }^{101}$ Since terminal services of LNG facilities involve a hybrid of importing and transportation activities, it is possible for the FERC to exercise jurisdiction over LNG facilities under either s. 3 of the NGA, which generally

In addition to state and local authorities with jurisdiction over LNG facilities, other federal agencies involved in regulating the design and operation of LNG terminals include the U.S. Environmental Protection Agency, U.S. Army Corp of Engineers and U.S. Customs Service and Transportation Security Administration. U.S., Energy Information Administration, Department of Energy, US LNG Markets and Uses (Washington, D.C.: Orfice of Oil and Gas, 2003) at 4. 46 U.S.C. $\$ 3703,46$ U.S.C. \$3305.

7 In February 2004, FERC, USCG and DOT signed an interagency agreement to supplement a 1985 agreement between FERC and DOT, and to coordinate the activities and information exchange of the agencies with regard to safety and security of LNG facilities, tanker operations and related marine concerns. 46 U.S.C. $\$ 70101-17$ (2003) [MTSA].

44 33 U.S.C. $\$ \$ 1501-24(2003)[D W P A]$.

11m) The present definition of decpwater port is "any fixed or floating manmade structurc other than a vissel, or any group of such structures, that are located beyond State seaward boundaries and that are used or intended for use as a port or terminal for the transportation, storage, or further handling of oil, or natural gas for the transportation to any State, except as otherwise provided in section 1522 of this title, and for other uses not inconsistent with the purposes of this chapter, including transportation of oil or natural gas from the United States outer continental shelf" (ibid. at $\$ 1502(9)(A)$. 
governs importing and exporting of natural gas, or s. 7 of the $N G A$, which governs the construction, operation and acquisition of facilities for interstate transportation and sales of natural gas. While the FERC has traditionally considered the assessment of authorizations under ss. 3 and 7 to be substantially equivalent, recent policy changes at the FERC have introduced subtle distinctions between the application of these sections including the necessity of conducting open seasons, maintaining tariffs and filing precedent agreements.

The FERC has historically assumed jurisdiction over siting, construction and operation of LNG terminals under $\mathrm{s} .7$ of the $N G A$, which requires a natural gas company to secure a Certificate of Public Convenience and Necessity (CPCN) in order to engage in transportation or sale of natural gas, or to acquire, operate, construct or expand facilities. Such an application requires, inter alia, submission of evidence by the applicant that the proposed operation, sale, service, construction, extension or acquisition "is or will be required by the present or future public convenience and necessity." 102 The relevant excerpt provides:

No natural gas company or person which will be a natural gas company upon completion of any proposed construction or extension shall engage in the transportation or sale of natural gas, subject to the jurisdiction of the Commission, or undertake the construction or extension of any facilities therefor, or acquire or operate any such facilities or extensions thereof, unless there is in force with respect to such natural-gas company a certificate of public convenience and necessity issued by the Commission authorizing such acts or operations. $^{103}$

However, the FERC has more recently assumed jurisdiction over the siting, construction and operation of LNG terminals under s. 3 of the $N G A,{ }^{104}$ which generally governs the importation and exportation of natural gas into and out of the U.S. ${ }^{105}$ Section 3 provides:

No person shall export any natural gas from the United States to a foteign country or import any natural gas from a foreign country without first having secured an order of the Commission authorizing it to do so. The Commission shall issue such order upon application, unless, afler opportunity for hearing, it finds that the proposed exportation or importation will not be consistent with the public interest. The Commission may by its order grant such an application, in whole or in part, with such modification and upon such terms and conditions as the Commission may find necessary or appropriate, and may from time to time, after opportunity for huaring, and for good cause shown, make suclı supplemental order in the premises as it may find necessary or appropriate. 106

IS U.S.C. $\$ 717 f(\mathrm{e})(2003)$.

lbid. \$7I7(c)(1)(A).

For example, authorization for the Everctl. Massachusetts LNG import facilities was granted to Distrigas Corp pursuant to section 3 of the NGA: Distrigas Corp. 47 F.P.C. (1972).

Pursuant to s. 30l(b) of the Department of Energy Organization Act, the regulatory functions of s. 3 were iransferred from the FERC to the Secretary of Energy. However, by DOE Delegation Orders Nos. 0204-112 (1984) and 00-04.000 (2002), the Secretary of Energy delegated back to the FERC the authority to approve the siting, construction. modification and operation of certain facilities, and the point of entry or exit for imports and expons.

15 U.S.C. $\$ 717 \mathrm{~b}(\mathrm{a})(2003)$. 
The FERC derives its jurisdiction over siting, construction and operation of LNG facilities from its authority to grant import or export applications "with such modification and upon such terms and conditions as the Commission may find necessary or appropriate."

While there are a number of distinctions between the application requirements of ss. 3 and 7 (including the fact that s. 7 provides for the potential exercise of powers of eminent domain, while $s .3$ does not), the FERC's jurisdiction under these sections has not always been exercised separately. In Distrigas Corp. v. FPC, the DC Circuit Court held that s. 3 conferred on the FERC "the equivalent of section 7 certification requirements both as to facilities and ... as to sales within and without the state of importation," ${ }^{108}$ and thus allowed the FERC to use its s. 3 authority to require the applicant to file an application under s. 7. Similarly, the s. 3 standard, which requires a finding that the application is "not ... inconsistent with the public interest," had historically been considered substantially equivalent to the $\mathrm{s.} 7 \mathrm{standard,}$ which requires a finding that the application is "required by the ... public convenience and necessity." 109 However, as FERC policy regarding the unique nature of LNG facilities has evolved, distinctions between applications under these sections have developed.

An example of the evolving distinction between ss. 3 and 7 applications is evident in the treatment of open access and tariff filing requirements. Under $\mathrm{s} .7$ applications, the FERC had tended to treat the LNG terminal as an integrated component of the interconnecting pipeline and, as a result, the terminal and terminal services had been regulated in the same manner as services provided by interstate pipelines. Due to the fact that the FERC had not made a distinction between treatment of the LNG terminal facilities and the interstate pipeline facilities that connect the LNG facility, LNG terminal services applications had traditionally complied with open access requirements (offering terminal services on an nondiscriminatory basis) and filing of tariffs for terminal services in the same manner as pipeline requirements. However, in December 2002, the FERC altered this policy in the Hackberry LNG decision 110 in which it granted authorization to construct the facility under s. 3 and dispensed with the need to provide open access or the filing of a tariff or rate schedule. As a recent academic article notes, this decision signalled a change in FERC policy indicating a willingness to regulate LNG facilities in the same manner as a source of natural gas supply rather than as a component of the transportation system:

The Commission determined that under the circumstances of this project, the LNG terminal should be treated as any other source of natural gas supply. In effect, the Commission decided to apply its full regulatory requirements and policies only when the re-vaporized natural gas leaves the L.NG terminal and enters the interstate pipeline facilities. Under the Commission's prior policy, its regulation would have applied at the point where the LNG leaves the tankers and enters the LNG terninal facilities. ${ }^{111}$

\footnotetext{
167) Ibid.

Ira 495 F.2d 1057 at 1062 (D.C.Cir. 1974), cert. denied. 419 U.S. 834 (1974),

Iiv) Ibid.

IIII Supra note 70.

III Gerald Knowles. "Liquefied Natural Gas: Regulation in a Competitive Natural Gas Market" (2003) 24 Energy L.J. 293 at 3 i I [footnotes omitted].
} 
As such, for regulatory purposes, the LNG terminal is treated as a source of production, rather than a component of interstate transportation.

As a further example of the evolving distinction between ss. 3 and 7 applications, in a rehearing on the Hackberry LNG matter in 2003, ${ }^{112}$ the FERC distinguished between the $s$. 3 standard and the s. 7 standard and dispensed with the need to file executed precedent agreements in s. 3 filings:

The standard for approving a project under Section 3 is diticent that from Section 7. Section 3 requires only that the applicant show that its proposal is "not inconsistent" with the public interest, unlike Section 7, which requires a finding that a proposal is "required by the present of future public convenience and necessity." In addition, under Section 3, an applicant has no power of eminent domain. Therefore, we see no need for Cameron to file its contracts for LNG terminalling service with the Commission. ${ }^{113}$

The decision to shift policy was based on the FERC's recognition that the regasified LNG would be sold at the outlet of the LNG facility in competition with other sales of natural gas that had been produced in a deregulated competitive environment, and that accordingly LNG should not be treated differently than other gas produced in the region. In addition, the decision to shift policy stems partly from arguments by industry participants that in order to commit substantial investment in the entire LNG value chain, including upstream liquefaction plants, ${ }^{114}$ companies needed to have assured access to terminalling services, which could be compromised if the terminal was subject to open-season bidding. The new policy, therefore, is partially intended to encourage further development of LNG facilities by removing what industry participants considered unpalatable regulatory requirements that introduced additional investment risks. According to Knowles, "[i]n the regulatory area, policies are required that will attract and facilitate the needed investment in additional LNG facilities. The new policies adopted by the FERC, with regard to LNG terminals, are intended to remove certain impediments to attracting the needed investment."'/s Dispensing with open access requirements, therefore, would attract development of LNG infrastructure, increase gas supply and control market costs of the commodity.

The FERC decision to dispense with the open access requirement for onshore LNG facilities also stems partly from an amendment to the DWPA, which prevents the DOT from imposing any open access requirement on deepwater port natural gas facilities. The FERC elected to follow a similar policy for onshore facilities to ensure that the regulatory requirements for onshore and offshore facilities would be consistent.

The FERC's exclusive exercise of jurisdiction over the siting, construction and operations of onshore LNG facilities has not, however, remained unchallenged. Following a s. 3 application by Sound Energy Solution on 26 January 2004, the Public Utilities Commission

104. F.E.R.C 961, 269. Due to the acquisition of Hackbtrry by Sempra Energy LNG Cotp, the project is now known as Cameron LNG.

Ibid. at para. 12.

The largest component in the LNG value chain is the liquefaction plant. which according to the Gas Teclinology Institute, can cost approximately (USD)\$I.5 to 2.0 billion for construction of a $390 \mathrm{Bcf}$ plant: Global LNG Market, supra note I at I.

Supra note 111 at 319. 
of the State of California (CPUC) asserted that the proposed LNG facility was a public utility and therefore fell within the jurisdiction of the CPUC. The CPUC contended that the FERC's jurisdiction under s. 3 of the $N G A$ was limited merely to authorizing the import of LNG and did not extend to the regulation of siting, construction or operation of the proposed LNG terminal itself. ${ }^{116}$ The FERC responded by reasserting its jurisdiction over siting, construction and operation of LNG facilities on the grounds that s. 3 authorizes the FERC to grant authority to import LNG "with such modification and upon such terms and conditions as the Commission may find necessary or appropriate." As such, the FERC argued that the regulation over siting, construction and operation of the LNG terminal arises as a condition of the authority to import LNG. In addition to noting that the FERC's exclusive jurisdiction over import/export facilities has been "routinely accepted by Congress, the industry, and State and Federal regulatory bodies," 117 the FERC also argued that the "nation's energy needs are best served by a uniform national policy applicable to LNG imports." "18 At the time of writing, however, the CPUC had not accepted the FERC's rationale, and it appears likely that the jurisdictional dispute will be resolved by the courts.

\section{Case Study: Fairivinds lng Receiving Termival Proposal}

In September 2003, Fairwinds, a joint venture of ConocoPhillips Company and TransCanada PipeLines Limited, ${ }^{119}$ proposed the construction of a $500 \mathrm{mmcf} /$ day LNG project near the town of Harpswell, Maine. It was proposed that the project would consist of an offshore LNG carrier berth and unloading jetty, two onshore storage tanks able to hold 160,000 cubic metres of LNG each (equivalent to $6.8 \mathrm{Bcf}$ of natural gas in gaseous state), a regasification facility including submerged combustion vaporizers to warm the $L N G$, and a 24-30 inch sendout gas pipeline with an operating pressure of 1,440 pounds per square inch. The estimated capital cost of the project was $\$ 350$ million, and it was anticipated that the project would be operational in 2009. Pursuant to a town plebiscite in March 2004, 56 percent of voters rejected the proposal by Fairwinds to lease a parcel of town land as the site for the LNG receiving terminal. While the joint venture was unsuccessful in securing a lease of the Harpswell site for the LNG terminal, the proposed lease, and stakeholder response to the proposal, provides an indication of the present issues and challenges involved in developing LNG terminal projects in the U.S.

\section{A. SITE. ISSUES}

Other than technical and economic risks, perhaps one of the most significant challenges for proponents of new LNG terminal facilities is identifying and securing an appropriate

A similar challenge to FERC jurisdiction occurred in 2001 in Dynegy LNG Production Terminal L.P. (Dynegy), 97 F.E.R.C. I 61, 231 (2001), in which it was argued that the Energy Policy Act of 1992. 42 U.S.C. $\$ 13201$ (1992), amended s. 3 io provide that importation of LNG should be considered a "first sale," and because first sales are outside of the jurisdiction of the NGA duc to the Natural Gas Policy Act of 1978, 15 U.S.C. $\$ 3301$ (1978), the FERC"s jurisdiction over LNG terminals (as derived from its authority over imports) had been removed. The FERC rejected the argument on the basis that Congress did not intend to remove its authorily over facilities associated with imports and exports.

Sound Energy Solutions, 106 F.E.R.C. ๆ 61,279 at para. 20 (2004).

Jbid. at para. 27 [emphasis added].

The views presented herein are those of the author and do not necessarily reflect the views of TransCanada, ConocoPhillips or any other party. 
location for the facility. In addition to environmental, technical and commercial considerations, it is imperative for project proponents to anticipate and address the safety, security and socio-economic concems of the surrounding community.

The proposed location for the Fairwinds project was identified following a site selection survey, which evaluated a number of sites based on economic, technical and environmental criteria. The site was identified as a potential location for the Fairwinds project on the basis of a number of favourable attributes. From 1954 to 1991, the site had served as a U.S. Navy fuel depot and, therefore, the proposed project was consistent with previous land uses and with the community's long-standing ties with the maritime industry. The site was considered technically feasible, since the navigational channels had sufficient depth to accommodate LNG carriers without the need for dredging, and the waterfront provided sufficient space for manoeuvring, docking and offloading LNG vessels. The proposed site was also considered commercially viable since it was proximate to existing major interstate natural gas pipeline infrastructure, thereby allowing gas from the proposed terminal to be delivered to market at competitive prices.

The site proposed for the Fairwinds project is owned by the municipality of the town of Harpswell, and the Fairwinds proponents had proposed a long-term lease of the property from the town. During negotiations with the town, to ensure that local residents had access to sufficient detail regarding the proposed project, Fairwinds produced and distributed a 115 page project description and impact document, which provided a detailed description of the proposed construction and operations of the facility, and addressed community impact and benefits, safety issues, water requirements, air and noise quality, vegetation and wildlife and soil and geology impacts. Such detailed descriptions may be necessary in the future to ensure stakeholders are sufficiently knowledgeable about the proposal to make informed decisions regarding terminal impacts and proposed land use. In addition, to address community and stakeholder engagement issues, Fairwinds also undertook to involve the community throughout the permitting, construction and operations phases of project development. Indeed, the project proponents offered to incorporate many of these commitments in the proposed lease of the site as a demonstration of this commitment. As such, Fairwinds proposed to include a number of environmental, technical and socio-economic commitments in the lease agreement, which are typically addressed in the regulatory forum and are unusual in agreements of this kind.

\section{Removal. AND REMEDIATION}

To address concerns regarding the adequate provision for, and expeditiousness of, the remediation of the leased site, Fairwinds proposed to create and maintain a trust fund for the purposes of addressing remediation costs at the termination of the lease. Periodically throughout the term of the lease. Fairwinds proposed to engage an expert in deconstruction, decommissioning and removal of large facilities to estimate and review the costs of remediation and decommissioning of the LNG facility. Similar to a sinking fund, Fairwinds proposed to contribute a proportionate amount of the ultimate remediation and decommissioning costs in each year of operations so that the trust fund would be fully funded and available for remediation and deconstruction by the end of the lease term. 


\section{LOBSTER AND SHELlfiSh Mitigation PROGRAM}

In response to acute local concerns regarding the impact of the LNG facility on the local fisheries industry, Fairwinds proposed a unique plan to mitigate and compensate for impacts of the LNG project on the fisheries industry. In addition to conducting studies and establishing procedures to identify and mitigate any adverse impacts to the ocean bottom habitat, the project proponents offered to collaborate periodically with industry organizations and community representatives during the operations of the LNG terminal to schedule shipping traffic to the facility at times of the day least disruptive to the local lobster fishing industry. In addition, the project proponents had proposed to construct the pipeline from the LNG facility during winter months in order to minimize disruption of fisheries migration, and had proposed to design the pipeline in such a manner as to reduce barrier impacts to fisheries migration and detrimental consequences to the maritime ecosystem.

\section{CONSUltation COMMITTEE}

As part of its commitment to community and stakeholder involvement in the project, and to facilitate timely communication with local representatives, Fairwinds proposed to develop a consultation committee, which would include representatives of the project and the local community, and which was intended to provide a forum for communication and involvement of local representatives in the design and operation of the LNG facility. Significantly, it was proposed that the consultation committee would be involved in all phases of the development of the project, including the permit, construction and operations phases, and not merely as an intervener during the regulatory permitting period. It was proposed that the consultation committee would have a dispute resolution function and would be empowered under the lease to address and attempt to forge mutually acceptable solutions to recreation, fishing, tourism, environmental impacts, safety and emergency response issues.

\section{SAFETY}

In addition to safety obligations under permits and regulations, Fairwinds proposed to commit to certain safety and security measures as contractual obligations under the lease. For example, as a part of federal regulation of safety issues, ${ }^{120}$ the FERC requires LNG facilities to control land within a safety exclusion zone surrounding the facility. While the FERC has not prescribed a definitive means of establishing this "control," it is possible that such control may be exercised by easements or land restrictions that prohibit the construction of buildings or gatherings of more than 50 people within the exclusion zone designated for the facility. In anticipation of the exclusion zone requirement, Fairwinds had proposed to lease sufficient acreage surrounding the LNG terminal to satisfy control of the expected exclusion zone for the project and had made provision to expand the acreage of leased property to address any addition or expansion to the exclusion zone that the regulators may have prescribed. In recognition of the potential need to expand the leased area to provide for the exclusion zones, Fairwinds had offered to provide replacement properties to the town as compensation for the loss of use of the lands in the expanded area. 


\section{SECURTY}

Security measures for land based LNG facilities and the onshore portions of marine terminals are identified in DOT regulations, ${ }^{121}$ and include provisions for security patrols, protective enclosures, lighting, monitoring and alternative power sources. Security measures for offshore portions of marine terminals are prescribed by USCG regulations, ${ }^{122}$ including security zones surrounding LNG vessels while in transit or docked. In addition to these requirements, Fairwinds had also proposed to collaborate with the local community to address security issues, including contingency and response planning, and to create a program to educate local residents about security measures for the facility.

While many of the foregoing issues relating to safety, security, consultation and remediation are typically addressed in the regulatory and permitting process, in recognition of the importance of community involvement, Fairwinds had proposed to address these issues as part of the lease of property. The project proponents had agreed to these significant and unique contractual obligations to ensure that community, socio-economic and environmental concerns continued to be associated with the ongoing use of the site itself and would be governed directly by the project and the community in the context of the landlord and tenant relationship, rather than merely addressed by regulators as part of the regulation of the facility as an LNG terminal. The lack of feasible locations for LNG terminals, coupled with general community reluctance to host energy infrastructure projects, suggests that such an involved and ongoing interaction between project proponents and the community will continue to be necessary in order to site facilities in North America.

\section{B. Terminalling SERVICES AGREement}

Since the Fairwinds joint venture was unsuccessful in securing a lease of the Harpswell site, negotiations in relation to a Terminalling Services Agreement were suspended. However, the experiences of other suppliers and terminal owners have proved to be instructive. As a result of the Hackberry LNG decisions, ${ }^{123}$ the manner of negotiating for terminal services has changed significantly. The FERC indicated that since the s. 3 "not inconsistent" test is different from the s. 7 "public convenience and necessity tests," it is not necessary for terminal owners to publicly file terminal services contracts as evidence of the need for the project in s. 3 applications. In addition, the FERC may authorize the terminal owner to sell terminal services at market based rates under s. $3,{ }^{124}$ and since the terms and conditions of the terminal services agreement would be privately agreed by the terminal owner and the customer, the FERC considers it unnecessary for the terminal owner to file

Ibid., Subpart J- Security.

Waterfront Facilities Handling Liquefied Natural Gas and Liquefied Hazardous Gas. 33 C.F.R. $\$ 127$ (1988).

Supra note 70 and 104 F.E.R.C. $\{61.269$ (2003).

The FERC may be less inclined to allow market bascd rates in relation to expansions of existing facilities. According to Southern LNG Inc. 103 F.E.R.C. \$ 61.029 (2003), it appears the FERC may require rolled in rates, rather than market based rales, in relation to an expansion of an existing LNG facility when existing customers pay cost of service based rates, since charging market based rates to new customers would effectively obligate the existing customer, who is contributing to the initial construction costs, to subsidize the expansion custumer. 
cost of service and estimated revenue information. ${ }^{125}$ Finally, since the FERC treats natural gas from the LNG facility to be equivalent to any other source of gas, the FERC has dispensed with the need to file a tariff or rate schedule for the terminal services. Consequently, this allows terminal owners and customers greater latitude to negotiate and customize terms for terminalling services without disclosing costs, rates, contractual terms or revenue information.

Terminal services agreements contain terms essentially similar to other throughput agreements. Of note, however, in terminal services agreements, the customer usually maintains responsibility for arranging shipping of LNG to the terminal and for obtaining authorization to import the LNG into the U.S. The customer is also responsible to ensure that LNG vessels properly interface with the LNG facilities and for ensuring the LNG meets identified quality specifications. The terminal owner will generally only take custody of the LNG and gas from the facility inlet to the outlet of the gas sendout facilities.

Given the significant investment and lengthy lead times involved in developing LNG projects, producers have a vested interest in ensuring adequate and cost-effective access to terminal services. Since FERC has dispensed with the requirement for the terminal owners to conduct an open season, customers can now negotiate committed access to terminal facilities concurrently with acquisition of upstream liquefaction services and shipping arrangements, and at an earlier stage in the development of LNG projects. Alternatively, producers may also be interested in being directly involved in the development and ownership of the terminal. If producers participate in the development or ownership of the terminal or are anchor suppliers to the facility, they will tend to have greater desire to synchronize long-term terminal services agreements to correspond with the terms and the duration of upstream production arrangements. In addition, customers may also seek commitment of stable terminal services rates so that the long-term economics of the integrated LNG value chain are more readily ascertainable from the outset. By contrast, smaller customers that have leased capacity in an LNG facility, or sellers more involved in LNG trading and spot markets, will tend to be more interested in flexible terminal services contracts with short durations to take advantage of short-term demand and price fluctuations.

\section{Case Study: Qatar Petroleum}

\section{A. The State of QATak}

The State of Qatar is an independent state in the Southern Arabian Gulf having a land border with Saudi Arabia and maritime boundaries with Saudi Arabia, Bahrain, the United Arab Emirates and Iran. The country extends over a peninsula approximately 160 kilometres long and between 55 to 100 kilometres wide, and covers a total area of 11,437 square kilometres, including a number of islands. The population of Qatar is approximately 800,000 , about one-third of whom are Qatari citizens, with the remainder being multinational expatriate workers and their families.

I:s However, the FERC reserved its jurisdiction under the s. 3 power to "make such supplemental order as it may find necessary or appropriate" to review rates and tariffs if it receives complaints of undue discrimination or anti-competitive behavior. 
In the last few years, Qatar's economy has demonstrated significant improvement on every account, exceeding expectations regarding export growth, diversification into LNG, fiscal health and the ability to service its debt. In 2002, gross domestic product was estimated at US\$16 billion (about 60 percent of which was derived from oil and gas). In 2002, per capita income was over US\$30,000, one of the highest in the world, and has seen an average annual growth rate over the past several years of approximately 10 percent.

Investment in Qatar's enormous LNG resource has paid off with impressive recent growth in LNG exports. LNG production commenced in 1996 through the Qatargas project. Current production of $14.4 \mathrm{mtpa}$ will increase to over $25 \mathrm{mtpa}$ by the end of 2005 upon completion of projects currently under construction, and to approximately $68 \mathrm{mtpa}$ by 2010 upon completion of currently planned projects. Clearly the stable political environment and transparent business climate of Qatar has attracted the attention of the world's major energy companies and financiers.

\section{B. Qatar Petroleum}

The State of Qatar conducts its oil and gas operations exclusively through Qatar Petroleum (QP), which controls the State's interests in all oil, gas, petrochemical, gas-to-liquids, fertilizer and refining enterprises in Qatar and abroad. QP was created in 1974 (as Qatar General Petroleum Corporation) by Emiri Decree and is engaged in all phases of the hydrocarbon business, including exploration and drilling, production, refining, transportation, storage, marketing, sales and exports.

As a result of the successful implementation of LNG projects developed in partnership with various international oil companies, QP has rapidly become one of the world's leading LNG producers.

QP currently employs approximately 7,000 people. At the end of 2002 , it had over US\$15.8 billion in assets and, in that year, over US\$8.5 billion in sales revenues (on a consolidated basis). QP has a long-term senior unsecured debt rating of A+ from Standard \& Poor's. QP does not have a Moody's rating separate from that of the State of Qatar, which is rated A3.

\section{The LNG Industry in The State of QATaR}

\section{INTRODUCTION}

In developing the resources of the giant North Field, Qatar has emerged in a relatively short time to become one of the world's leading exporters of LNG. The addition of new production trains to the existing Qatargas and Ras Laffan (or "RasGas") projects are increasing this export capacity in a manner that is much more cost-effective than building greenfield export facilities. The implementation of recently announced additions to production capacity (discussed below) is expected to soon make Qatar the world's largest exporter of LNG. Qatar's cost advantage and geographic location enables it to sell into markets worldwide. Qatar is currently the only LNG supplying nation to have major longterm LNG sale and purchase agreements (SPAs) with destinations both east and west of the Suez Canal. 


\section{THE NORTH FIELD}

Qatar is the third largest holder of gas reserves in the world, with the North Field containing the vast bulk of these reserves. The North Field, discovered in 1971, is the world's largest single, non-associated gas field. The field currently accounts for approximately 9 percent of world proven gas reserves, with proven gas reserves exceeding 900 trillion standard cubic feet (equivalent to approximately 150 billion barrels of oil).

The North Field extends over an area of 6,000 square kilometres predominantly underlying the waters to the northeast of the State of Qatar. A portion of the North Field underlies the Qatari land mass and a portion extends into the territorial waters of Iran (where it is known as the South Pars Field). Qatar and Iran concluded a maritime border agreement in 1969 , and the boundary between the two countries is not disputed.

\section{Fundamental LNG Project Documentation}

Each Qatari LNG project involves a vast number of contracts, usually broken down into the following broad categories: fiscal, joint venture-related, EPC, operational, shipping, marketing and project financing. However, the three fundamental project documents are the Development and Fiscal Agreement, the Joint Venture Agreement and the Sale and Purchase Agreement, the basic terms of which are usually agreed within the initial "Heads of Agreement."

\section{a. The Development and Fiscal Agreement (DFA)}

The DFA is the document by which the Government of the State of Qatar grants to the project sponsors and the project company the rights to allocated gas reserves and sets forth the related fiscal terms on which the joint venture will be developed. It is the basic grant of rights document in all Qatari LNG projects, with the exception of the Qatargas I project (the upstream portion of which is governed by a production sharing agreement, as described below). The DFA sets out in detail the specific rights granted to the project, including the gas supply rights (usually capped in terms of mtpa of resulting $L N G$ production). The fiscal terms are also set out in detail and will generally include the gas, condensate and LPG royalties payable to the State, the applicable tax regime (including any tax paid-on-behalf provisions, income tax rates and tax exemptions) and any economic stabilization rights. The choice of governing law is always Qatari law. The DFA becomes effective upon its approval by Emiri Decree.

\section{b. The Joint Venture Agreement (JVA)}

The JVA provides for the establishment of the LNG project company (which will be a Qatari company). It sets out the framework to be employed by the company and the necessary governance between the shareholders of the company to implement the LNG project pursuant to the DFA. The parties to the JVA are the initial shareholders, being Qatar Petroleum (usually with a 70 percent equity interest) and a subsidiary of the foreign partner (usually with a 30 percent equity interest). Once the project company is formed, it will usually sign a separate document by which it will agree to be bound by the JVA as if it were a party to it. In some cases, as will be mentioned below, LNG project companies may also admit 
subsequent minority shareholders who have demonstrably "added significant value" to a project (either by being a long-term off-taker of a large amount of LNG or by providing financing to the project or to one of the principal shareholders). However, these minority shareholders usually participate only in a profit centre that relates to their value-added portion of the project. The JVA will be amended and restated when such a minority shareholder accedes to it. The JVA will be coterminous with the DFA. It will generally be governed by Qatari law.

\section{c. The LNG Sale and Purchase Agreement (SPA)}

Traditionally, a LNG project depends upon one or more SPA for the majority of its revenues. In some cases (such as Qatargas I, Ras Laffan I and Ras Laffan II), the SPAs that fundamentally support the project are long-term SPAs for fixed quantities with third-party buyers. In other cases (such as Qatargas II, Qatargas III and the Ras Laffan II U.S.A. project), the project company will enter into one large SPA with a buyer that will encompass the full output capacity of the LNG trains owned by the project for its full term. The buyer will be an affiliate of the foreign partner. In either case, the SPAs form the foundations of these projects and the particular terms and conditions of these SPAs, as well as the creditworthiness of the buyers (or the credit support structures put in place by the buyers), which will be fundamental in the financing of the upstream LNG projects. All existing Qatari SPAs are 100 percent take-or-pay contracts and are structured on either "free on board" (fob), "cargo and freight" (cfr) or "ex ship" shipping terms.

In view of the rich nature of North Field gas, a significant proportion of an LNG project's revenues will also be derived from sales of other petroleum products, chiefly condensates and LPGs. The sale of these products are also used to underwrite the financing of the projects.

\section{The Qatargas Projects}

\section{a. The Original Qatargas Project}

The Qatargas project was the first of Qatar's LNG projects. Project development started in 1993 with the first LNG production and condensate deliveries in 1996. The Qatargas project is divided into two separate components: the upstream component and the downstream component. The upstream component consists of the development of an offshore block of the North Field reservoir for the extraction of natural gas at offshore production platforms and the transportation of the gas via a single 32-inch diameter undersea pipeline to onshore reception facilities located at Ras Laffan Industrial City (RLIC). At RLIC, the field condensate accompanying the natural gas is removed prior to transfer of the gas to the downstream component of the project. The downstream component consists of the LNG plant at RLIC that processes the natural gas and prepares it for export as LNG from the RLIC port, operated by QP.

The downstream component of the Qatargas Project is owned and operated by the Qatar Liquefied Gas Company Limited (Qatargas), established pursuant to a joint venture agreement among the shareholders. QP owns 65 percent of Qatargas. Subsidiaries of Total S.A. and Exxon Mobil Corporation each own 10 percent and subsidiaries of Mitsui \& Co. Ltd. and Marubeni Corporation each own 7.5 percent. These shareholders also formed an 
unincorporated joint venture to invest in and develop the upstream component of the Qatargas Project. Sixty-five percent of this upstream venture is owned by QP, with the balance owned by subsidiaries of Total S.A. (20 percent), Exxon Mobil Corporation (10 percent), Mitsui \& Co. Ltd. (2.5 percent) and Marubeni Corporation (2.5 percent). This upstream venture is governed by a production sharing agreement among the State of Qatar and each of the participants, and is operated by Qatargas under the terms of a separate joint venture agreement.

The Qatargas offshore complex is currently capable of producing and treating 1.45 Bcf/day. The LNG plant consists of three identical LNG trains, as well as storage and loading facilities, and off-site and utility systems required for the production of the plant's output of LNG. In addition to LNG, the plant produces condensate and sulphur for export. The total nameplate design capacity of the three trains was $6 \mathrm{mtpa}$ of LNG. However, increasing efficiency of operation and experience has increased this volume so that actual LNG production in 2002 was $7.82 \mathrm{mtpa}$. Additional investment in de-bottlenecking to increase production capacity to over 9 mtpa started in 2002 and is expected to be completed in 2005 .

In 1992 and 1994, Qatargas entered into two LNG sale and purchase agreements with Chubu Electric Power Company of Japan (Chubu Electric) and seven other Japanese utility companies. In the first agreement Chubu Electric is the sole LNG buyer; however, in the second Chubu Electric acts as the buyers' coordinator on behalf of the other Japanese utility companies. The sale and purchase agreements provide for the supply of LNG by Qatargas over a 25-year period that commenced on 1 January 1997. Contract volumes across the two contracts total 6 mtpa of LNG (after an initial supply buildup period that ended in 2000). In 2002, Qatargas delivered 105 cargoes to Japan, with 74 cargoes delivered to Chubu Electric and 31 cargoes delivered to the other seven Japanese buyers. By June 2003, the total deliveries to the eight Japanese buyers since inception of the contracts had reached 510 cargoes ( 31 mtpa of $L N G$ ).

Qatargas is responsible for the transport of LNG to Japan under the Chubu SPAs. It has a fleet of ten LNG vessels delivering to Japan, each with a capacity of 135,000 cubic metres. In addition, Qatargas has a number of vessels under short-term charter for delivery of spot sale cargoes.

Separately from its commitments to Qatargas's long-term Japanese customers, 13 nonJapanese buyers had purchased 124 cargoes of LNG (in excess of $6.3 \mathrm{mtpa}$ ) from Qatargas during the period from start-up through 1 June 2003. Spain has been Qatargas's largest market to date for mid-term and spot sale cargoes, with sales to Gas Natural accounting for approximately 69 percent of all such sales. In May 2001, Qatargas signed two medium term SPAs with Gas Natural for the supply of $1.4 \mathrm{mtpa}$ of LNG starting in 2001. In October 2002, Qatargas signed an agreement with BP to sell $0.75 \mathrm{mtpa}$ of LNG into Europe and the first cargo was lifted in December 2003.

\section{b. The Qatargas II Project}

The new Qatargas II project will be implemented pursuant to a JVA to be entered into between QP and ExxonMobil. The project currently anticipates the development of a two large train LNG project for the production and supply of LNG directed to the U.K. market. 
The principal terms for the JVA were agreed in a Heads of Agreement signed by QP and ExxonMobil in June 2002. QP will own 70 percent of the shares of Qatargas II and ExxonMobil will own 30 percent. Taking account of all elements of the project structure contemplated by the parties and their affiliates, the Qatargas II project will be the world's largest integrated energy project (at least until the Ras Laffan II U.S. Project is implemented, as discussed below). It will be the first LNG project for which the participants intend to build a downstream $L N G$ receiving terminal in addition to the upstream production facilities. It will employ the largest LNG carriers and it will be the first LNG project where an affiliate of a major shareholder in the project company will be the buyer of the LNG on a take-or-pay basis.

Two LNG trains, each with a rated capacity of $7.8 \mathrm{mtpa}$, will be built on the existing Qatargas site located in RLIC. Qatargas II will be developed in two phases. The engineering, procurement and construction contract for the first of the two trains is scheduled to be awarded in the fourth quarter of 2004, with first delivery of LNG in the U.K. expected in early 2008. The second train is expected to be built approximately two years after train 1 , with the timing driven by market demand. The full project scope includes the following four principal physical components:

1. Offshore production platforms and pipelines;

2. Onshore gas treating and LNG facilities;

3. LNG ships (the current fleet configuration assumes several vessels with capacities up to 185,000 cubic metres and larger ships are being considered); and

4. A receiving terminal in the U.K.

Qatargas II will develop, finance and own the offshore and onshore facilities. Qatargas II will enter into an ex ship LNG SPA with a U.K. corporation owned by subsidiaries of QP and ExxonMobil (Tradeco). At the time of writing, a final decision regarding Qatargas II (or an affiliate) owning the LNG ships or chartering the ships from third-party owners is still under consideration. A U.K. corporation owned by subsidiaries of $Q P$ and ExxonMobil (Termco) will develop, own and finance the U.K. terminal. Tradeco will own the LNG as it is regasified within the receiving terminal (while paying terminal charges to Termco), and will then sell the resulting gas ex terminal to an affiliate of ExxonMobil pursuant to a gas SPA.

\section{c. The Qatargas III Project}

In July 2003, QP and ConocoPhillips Company signed a Heads of Agreement for the development of the Qatargas III project. Qatargas III is planned as the first integrated LNG project in Qatar to be targeted exclusively at the U.S. market. It centres on the construction of a $7.8 \mathrm{mtpa}$ train at the Qatargas complex and will be owned by a new joint venture company of QP (70 percent) and ConocoPhillips (30 percent). The Heads of Agreement provide for a feasibility study to be carried out on all aspects of the project, which includes the development of upstream facilities in the North Field, the new gas train at RLIC and a fleet of LNG tankers. This study is currently underway, as is the negotiation of the three major project agreements: the DFA, the JVA and the LNG SPA. It is currently anticipated that ConocoPhillips will purchase all of the LNG produced by the train ex ship and will be responsible for regasification and marketing in the U.S. QP has the right to elect to take an 
equity position in the U.S. terminal, in which case the structure would closely match what is set out above with respect to Qatargas II. Plant start-up is anticipated for 2008 or 2009.

\section{d. Qatargas OPCO}

Given the integrated nature of the Qatargas, Qatargas II and Qatargas III projects, it is seen as cost-effective and efficient for the upstream portion of the projects to be operated, maintained and administered by a single operating company. The sponsors of all of these projects expect to form "Qatargas OPCO" (the name has not yet been selected) to undertake this role. In order to staff this new entity, it is envisaged that the current employees and secondees of Qatargas will become employed by, or seconded to, Qatargas OPCO. Operation of the facilities will be handled in accordance with instructions given to Qatargas OPCO by the project companies under the terms of a Services Agreement for Operation and Maintenance. The Qatargas OPCO JVA, which is currently being negotiated, will set out the commercial framework through which Qatargas OPCO will be established.

\section{The Ras laffan (OR Rasgas) Projects}

\section{a. The Original Ras Laffan Project}

The Ras Laffan Project was the second major LNG venture established in Qatar for the development of North Field gas. Unlike Qatargas, the original Ras Laffan Project was conceived as a fully integrated project in which the offshore gas production and onshore LNG manufacture would both be owned by the project company, Ras Laffan Liquefied Natural Gas Company Limited (Ras Laffan). RasGas Company Limited (owned 70 percent by $Q P$ and 30 percent by a subsidiary of ExxonMobil Corporation) operates both the Ras Laffan Project and the subsequent expansion of that project, known as the Ras Laffan II Project (described below).

The Ras Laffan Project was established in 1993 and was granted the right by the Government of Qatar (pursuant to a DFA) to drill and produce natural gas from Qatar's North Field and to sell LNG from Qatar, together with the right to produce and sell associated condensate and hydrocarbon by-products.

The Ras Laffan Project involved the development of an offshore complex, to produce and treat 1.1 Bcf/day of gas, together with the construction of two LNG process trains, each capable of producing $3.3 \mathrm{mtpa}$ of LNG. The total capital costs were in excess of US\$3 billion, and the first LNG shipment was made in June 1999. In addition to LNG, Ras Laffan produces over 43,000 barrels of condensate and 300 tons of sulphur per day.

QP originally held a 70 percent stake in the Ras Laffan Project, with ExxonMobil RasGas Inc. (a wholly owned subsidiary of ExxonMobil Corporation) holding the remainder. This was amended to 66.5 percent (QP) and 26.5 percent (ExxonMobil RasGas Inc.) as a result of two Japanese trading houses taking stakes of 4 percent and 3 percent in 1996. As the foundation purchaser of LNG from the Ras Laffan Project, Korea Gas Corporation (Kogas) was granted the right to acquire a 5 percent stake in the project for which discussions are still in progress. 
Under an SPA signed with Kogas in 1995 and amended in 1997 (the Kogas SPA), Ras Laffan is currently supplying Kogas with $4.92 \mathrm{mtpa}$ of LNG. The first delivery of LNG under the contract was made in August 1999 and plateau contract volumes were reached in 2002.

In 2002, Ras Laffan produced six mtpa of LNG and shipped 77 cargoes to Kogas. The company has enjoyed considerable success in marketing production capacity in excess of that required for the Kogas SPA, resulting in a further 28 cargoes being delivered on the spot market in 2002.

b. The Ras Laffan II (or RasGas II) Project

(i) Facilities

Ras Laffan II is currently owned by QP ( 70 percent) and ExxonMobil RasGas Inc. (30 percent). The Ras Laffan complex is being expanded through a sister company, Ras Laffan Liquefied Natural Gas Company Limited (II) (Ras Laffan II), by the addition of a further two trains (trains 3 and 4). This expansion was accompanied by an additional DFA from the State, granting LNG production rights.

Trains 3 and 4, which are currently under construction (train 3 is being commissioned at the time of writing), are the largest LNG trains ever built and are expected to have a combined LNG production capacity of $9.4 \mathrm{mtpa}$. When completed, they will bring the total LNG production capacity of the Ras Laffan complex (including trains I and 2 of Ras Laffan 1) to $16 \mathrm{mtpa}$. The total capital costs of the Ras Laffan II facilities are expected to be US\$2.5 billion, with production from the third train scheduled to begin in early 2004. The target completion date for train 4 is September 2005 and the project is on schedule.

\section{(ii) Sales Agreements}

In July 2003, Ras Laffan II and India's Petronet LNG Limited ${ }^{126}$ (Petronet) amended a long-term SPA signed in 1999, pursuant to which Ras Laffan II will supply $5.0 \mathrm{mtpa}$ of LNG to India. The first LNG shipment was delivered to Dahej in the Indian state of Gujarat in December 2003 (using uncommitted capacity from Ras Laffan I, pending completion of train 3). Full contract volume is scheduled to be reached in 2006. The SPA also contemplates the supply to Petronet of a further $2.5 \mathrm{mtpa}$ for delivery to the Indian market.

A long-term agreement to supply 3.5 mtpa of LNG to the Italian energy group Edison Gas was signed in June 2001; however, the final details of the supply arrangements are still under discussion. Under this SPA, the LNG will be delivered to a terminal 12 kilometres offshore of Rovigo in the northern Adriatic. QP and ExxonMobil have agreed, through their respective subsidiaries, to take a majority of the equity of the Italian terminal company. First delivery is expected to occur in 2007. 
In July 2003, Ras Laffan II signed a long-term SPA with Endesa Generacion SA of Spain (Endesa) for the supply of $0.8 \mathrm{mtpa}$ of LNG, with deliveries scheduled to commence in April 2005. Endesa, the largest electricity generating company on the Iberian Peninsula, supplies approximately 40 percent of Spain's power requirements.

Ras Laffan II also recently signed a Heads of Agreement with Taiwan's Chinese Petroleum Corporation (CPC) for the supply of $3 \mathrm{mtpa}$ of LNG to Taiwan. The SPA is currently under negotiation. CPC owns Taiwan's only existing LNG terminal and is currently the only LNG importer in Taiwan. It recently won a tender (based on the Ras Laffan II Heads of Agreement) to supply Tatan Power with $1.68 \mathrm{mtpa}$ of LNG. CPC will use the additional $1.32 \mathrm{mtpa}$ of LNG to supply the extension of existing contracts. First delivery of LNG to Taiwan is expected in 2008.

Ras Laffan II has signed three long-term charter party agreements for LNG vessels, principally to transport train 4 production (the Petronet sale is on a FOB basis), and has recently exercised options on a further three vessels. Expected delivery is in 2004/2005.

The Ras Laffan II U.S.A. Project

In October 2003, QP and ExxonMobil Corporation signed a Heads of Agreement for the supply of $15.6 \mathrm{mtpa}$ of LNG from Qatar to the U.S. for at least 25 years. This will result from a further two large LNG trains to be developed by Ras Laffan II (trains 6 and 7). These trains, similar to those being developed for the Qatargas II Project, will each produce 7.8 mtpa of LNG. This project will likely have a structure similar to the Qatargas II structure, involving upstream facilities, onshore LNG production facilities, large LNG tankers and a terminal in the U.S. The total investment, including shipping, is estimated at approximately US\$ 12 billion. The scheme is the largest LNG import project that has been announced for supplying natural gas to the U.S. First delivery of LNG is projected for 2008/2009. The basic project documentation will involve amendments to the existing Ras Laffan II JVA and DFA, and a new ex ship LNG SPA with either "Tradeco" (as in Qatargas II) or a wholly owned affiliate of ExxonMobil. Negotiations on the final structure and the detailed documents are currently proceeding.

\section{c. Ras Laffan OPCO}

As described above with respect to Qatargas OPCO, there exist many efficiencies in utilizing common operatorship across the Ras Laffan projects. In July 2002, Ras Laffan I transferred all of its personnel to RasGas Company Limited (RasGas OPCO), a company owned 70 percent by Qatar Petroleum and 30 percent by ExxonMobil, and entered into a services agreement with RasGas OPCO. In accordance with terms of this agreement, RasGas OPCO provides all of Ras Laffan's and Ras Laffan Il's operational, maintenance and administrative functions.

In addition to the services provided to Ras Laffan, RasGas OPCO provides similar services to Ras Laffan II and the Al-Khaleej Gas Project (a gas pipeline project undertaken by a subsidiary of ExxonMobil Corporation). In the future, it is also contemplated that RasGas OPCO will provide similar services for a project located at RLIC to produce helium. As of 31 December 2003, RasGas OPCO had 870 employees based in Qatar, of which 
approximately 150 were engaged solely in expansion related activities on behalf of Ras Laffan II and the Al-Khaleej Gas Project. As a result of greater efficiencies obtained through these arrangements with RasGas OPCO, neither Ras Laffan nor Ras Laffan II have active employees.

\section{FinanCING QATARI LNG Projects}

Project financing for the downstream portion of the original Qatargas project closed in April 1995. The facility agreements provided for US\$1.9 billion of commercial bank and export credit agency (ECA) debt. The last of this debt is scheduled to be retired in August of 2007. Project financing for the upstream portion of the original Qatargas project closed in December 1996, with approximately US\$570 million having been raised from ECAs and commercial banks. This debt was retired in June 2001.

The project finance plan for Qatargas II is still under development, but it is expected that senior debt for phase one (approximately half of the US\$12 billion project cost) will constitute 70 percent of the total sources of funds required. This massive amount of debt will be required from a variety of sources, including commercial banks, ECAs, Islamic institutions and monoline insurers. An affiliate of ExxonMobil Corporation will fund $\mathbf{3 0}$ percent of the senior debt by facilities with terms that match those of each third-party facility. QP will fund its own equity. Qatargas II's financial close is expected to occur in the fourth quarter of 2004. The financing plan for Qatargas 111 is still in its infancy.

Financing for the Ras Laffan project closed in December 1996, when Ras Laffan issued US\$1.2 billion of senior secured bonds and entered into arrangements with commercial banks and ECAs for commitments totalling US\$1.35 billion. Ras Laffan used the proceeds from these financings together with equity contributed by shareholders to construct train 1 and train 2 facilities and the offshore facilities. QP obtained financing for its equity through loan agreements with certain Japanese trading companies. At the time of writing, the remaining bank and ECA debt is being refinanced through the issuance of US\$665 million of new senior secured bonds. Ras Laffan II has not yet entered into any project financing arrangements regarding the construction of trains 3 and 4 and the related LNG vessels.

These past financings, and future ones, have had to consider a number of particular legal challenges that arise in project financings in Qatar, which include (in no particular order):

Assignments. Although Qatari law recognizes the assignment of rights, in order for such rights to be enforceable against the obliger in priority to an unsecured third-party creditor of the obliger, the consent of the obliger is required and must be of a certain date (thus requiring notarization and often legalization).

Bankruptcy and Insolvency. There is no bankruptcy or insolvency law in Qatar. However, the Companies Law provides that companies having a public corporation (such as QP) as a shareholder will be subject to the agreements entered into between the founders at the time of incorporation. Therefore, the provisions of the Articles of Association of the project company relating to winding up, liquidation and dissolution are used and enforced. 
A System for the Perfection of Security Interests. The law of the State of Qatar is relatively undeveloped with respect to perfection of security interests. There currently exists no effective registration system. To address lender concerns regarding the perfection of security over project assets, two forms of security structure have been used in project financings in Qatar: SPV structure and rights structure.

\section{a. SPV Structure}

This involves the establishment of an offshore special purpose vehicle in a jurisdiction with established laws dealing with the creation and perfection of security interests (usually the Cayman Islands). The project company will enter into an agreement with the SPV pursuant to which the project company will transfer all of its assets to the SPV, followed by another agreement pursuant to which the assets are conditionally transferred back to the project company; however, title remains with the SPV until the project financing is repaid. The SPV grants security over its rights in the agreements for the benefit of the lenders and guarantees repayment of the project debt. Unfortunately, this method has proven to be cosily and complex, and its efficacy is questionable. Therefore, it has recently fallen out of favour.

\section{b. Rights Structure}

This method has been employed in most of the recent project financings in Qatar. It involves the lenders taking limited security, which will be over: (a) the project company's interests in the project documents; (b) the project company's interests in the insurance policies; and (c) the project company's offshore bank accounts. There is no attempt by the lenders to take security over tangible project assets. This structure requires various security agreements, a security trustee who will hold legal title to the benefit of the security package and various direct agreements. The State of Qatar still requires a "pre-emptive right" in the event that lenders seek to realize on security in a foreclosure situation.

\section{FACHLITY SHARING}

The sharing of facilities has obvious benefits in achieving savings on capital and operating expenses and in increasing efficiencies and cooperation. Facilities are shared among all of the LNG projects at Ras Laffan Industrial City. Precedents for facilities sharing between Qatari joint ventures have been established by the Qatargas/RasGas facilities, services and data sharing agreement. Facilities sharing also occurs within the Ras Laffan LNG project (to the exclusion of the Qatargas projects) pursuant to the Ras Laffan LNG/Ras Laffan LNG II/Al-Khaleej Gas Facilities Sharing Agreement. A similar facilities sharing regime within the Qatargas project companies (Qatargas I, Qatargas II and Qatargas III) is expected to be developed within a new Qatargas Facilities Sharing Agreement. All of these agreements provide for a licensing arrangement through which ownership of the assets is retained by the original owner and the sharing party pays licence fees to the owner of the asset based on the agreed shared usage. The facilities that are currently being shared under these agreements include the condensate loading berth, the solid sulpluur storage and loading berth, plant condensate tankage and pipelines, and the plant ethane and propane storage line interconnects. Opportunities for future sharing that have been identified include the sharing of office buildings; condensate storage, loading lines and berths; LPG storage, loading lines and berths; warehousing and workshops; sulphur handling; desalinated water supply; fire 
protection; control rooms and laboratories; and offshore living quarters, power and control facilities.

\section{Conclusion}

While the liquefaction process has been developed and refined for a number of decades, and importation of LNG is an accepted practice in the Middle East, Japan, South Korea and parts of Europe, it is a relatively new source of supply in North America. However, increased North American demand for natural gas, coupled with diminishing production from accessible basins in Western Canada, and the reduced costs and efficiencies of ships, liquefaction plants and storage terminals have rendered $L N G$ a viable and price competitive supply alternative. Since the production, transportation and importation of LNG involves the entire value chain, the LNG industry provides unique challenges to producers, regulators, consumers and stakeholders. Producers must not only negotiate development, joint venture and sale and purchase agreements, but also arrange for shipping and transportation and terminal services agreements. In the Middle East, state governments and corporations have actively collaborated to produce and develop LNG sources. In North America, while regulators have divided jurisdiction over LNG terminal facilities on the basis of the location of the facility, the stage of production and the degree of integration with related infrastructure, they also appear to be encouraging further development by facilitating regulatory approval. As the Qatar Petroleum and Fairwinds projects demonstrate, the evolution of the LNG industry is dependent upon a delicate collaboration of governments, regulators, producers, financiers, consumers and stakeholders. 